NBER WORKING PAPER SERIES

\title{
GENDER BASED OCCUPATIONAL SEGREGATION AND SEX DIFFERENCES IN SENSORY, MOTOR AND SPATIAL APTITUDES
}

\author{
Michael Baker \\ Kirsten Cornelson \\ Working Paper 22248 \\ http://www.nber.org/papers/w22248 \\ NATIONAL BUREAU OF ECONOMIC RESEARCH \\ 1050 Massachusetts Avenue \\ Cambridge, MA 02138 \\ May 2016, Revised February 2018
}

We gratefully acknowledge the research support of the Social Sciences and Humanities Research Council (\#410-2011-0724) and a Canada Research Chair at the University of Toronto. Fran Blau kindly provided the occupational crosswalk for the 2000 Census occupational coding. We thank Dwayne Benjamin for helpful discussions, and Diane Halpern and Gary Solon for their input on an early draft. We also thank seminar participants at UBC-Kelowna and UBC-Vancouver. The views expressed herein are those of the authors and do not necessarily reflect the views of the National Bureau of Economic Research.

NBER working papers are circulated for discussion and comment purposes. They have not been peer-reviewed or been subject to the review by the NBER Board of Directors that accompanies official NBER publications.

(C) 2016 by Michael Baker and Kirsten Cornelson. All rights reserved. Short sections of text, not to exceed two paragraphs, may be quoted without explicit permission provided that full credit, including $(\subset$ notice, is given to the source. 
Gender Based Occupational Segregation and Sex Differences in Sensory, Motor and Spatial Aptitudes

Michael Baker and Kirsten Cornelson

NBER Working Paper No. 22248

May 2016, Revised February 2018

JEL No. J16,J24,J62,J71

\begin{abstract}
Research on sex differences in humans documents gender differences in sensory, motor and spatial aptitudes. These aptitudes, as captured by Dictionary of Occupational Titles (DOT) codes, predict the occupational choices of men and women in the directions indicated by this research. We simulate that eliminating selection on these skills reduces the Duncan index of gender based occupational segregation by 20-23 percent in 1970 and 2012. Eliminating selection on DOT variables capturing other accounts of this segregation has a smaller impact.
\end{abstract}

\author{
Michael Baker \\ Department of Economics \\ University of Toronto \\ 150 St. George Street \\ Toronto, ON M5S 3G7 \\ CANADA \\ and NBER \\ baker@chass.utoronto.ca \\ Kirsten Cornelson \\ Department of Economics \\ University of Toronto \\ 150 St. George Street \\ Toronto, ON M5S 3G7 \\ CANADA \\ kirsten.cornelson@utoronto.ca
}




\section{Introduction}

The male/female gap in labor market compensation has declined significantly over the past three decades in many developed countries. In the U.S., the female/male ratio of median annual earnings for full time workers has increased from 0.62 in 1979 to 0.83 in 2014 (Bureau of Labor Statistics 2015). In countries that measure the gender gap in hourly earnings the female/male ratio is even higher-for example, in 2014 it was 0.88 in Canada (CANSIM) and in 2015 it was 0.91 in the UK (Office for National Statistics 2015). In comparison, the pace of change in the gender segregation of employment in recent decades has been glacial. In an early study of gender occupational segregation, Gross (1968) reported that the Duncan index ${ }^{1}$ of segregation was steady at roughly 0.67 from 1900-1960. In the five decades since then, it has fallen by just 25\%, to just over 0.50 in 2012. Most of this convergence was in the 1970's and 1980’s; Blau et al. (2013) report that while the Duncan index declined by over 10 percentage points in the 1970s and 1980s, it declined by just over 3 percentage points in the following two decades. The index tells us that the overall segregation of males and females remains substantial: in recent years over half of men (or women) would need to change occupations for the occupational distributions of male and female employment to be the same.

It is important to understand why gender occupational segregation persists. It accounts for part of the remaining gap between male and female compensation-the within-occupation wage gap fell by nearly 50\% from 1970 to 2012, while the between-occupation component of the wage gap (the part related to gender occupational segregation) rose slightly. Persistent segregation of the genders across occupations implies that sectoral change that accompanies economic growth is likely to have important effects on the relative compensation of men and

\footnotetext{
${ }^{1}$ The Duncan index, which is defined below, ranges between 0 and 1 and is interpreted to indicate the proportion of women or men who would need to change occupations to produce a similar occupational distribution of men and women.
} 
women. Finally, if occupational segregation is of intrinsic policy interest, an effective response must be rooted in an understanding of its sources.

A large literature that attempts to explain occupational segregation has focused on three classes of explanations: gender differences in skills and human capital, gender differences in preferences for job characteristics, and gender based discrimination. In this paper, we extend the literature relating gender differences in skills to occupational choice by examining the potential importance of sex differences in a set of labor market aptitudes and skills that, to our knowledge, have not been systematically highlighted in research on gender based occupational segregation. Our focus is gender differences in sensory, motor and spatial aptitudes—-for example, the sense of touch, fingering abilities and depth perception. There is extensive research documenting differences between males and females in these skills, many starting at very young ages. While these skill differences have received less attention than gender differences in other traits, they are nevertheless clearly relevant to job skills in many occupations.

We map the evidence of sex differences in these aptitudes into occupational aptitudes, physical requirements, working conditions and temperaments as captured by the Dictionary of Occupational Titles (DOT, see for example, U.S. Department of Labor Employment and Training Administration 1991). We next relate these codes to different patterns of occupational selection by men and women. With few exceptions, females and males select into occupations on the DOT occupational attributes in accordance with the predictions of the research on gender differences in motor, sensory and spatial skills, suggesting that the "lab" evidence has some implications for economic life. These relationships largely remain once we control for other explanations of gender occupational segregation, including measures of math and verbal demands, physical strength, people/things orientation, "occupational risk" (risk of death, competition and prestige), 
and time flexibility.

The relationships between these skills and job selection are quantitatively important. Using simulations, we show that eliminating the observed correlation between these skill demands and male/female selection would reduce occupational segregation by about $20 \%$ in 1970 and 23\% in 2012. This is relatively larger than the combined effect of variables representing more traditional explanations of gender segregation.

A qualification to these conclusions is that it is difficult to identify the effect of specific job characteristics on occupational selection or wages because they may be correlated with other important characteristics that are unobserved. Gender differences in these unobserved characteristics, rather than our measures of physical, motor and spatial skills, could potentially be driving the differential male and female selection that we observe in our data. Also unobserved is any demand side employer discrimination that drives occupational segregation. For example, to use a better known gender difference, it may be that males are found disproportionately in jobs requiring physical strength, not because they are stronger on average, but because employers in these occupations are more discriminatory towards females.

To some extent, these concerns are mitigated by the fact that we are jointly testing for the effect of multiple skills. It is highly unlikely that we would observe the precise pattern of selection predicted by the extensive literature on these gender differences along a large number of skill measures if this selection was not in some way related to these skills. Additionally, we control for variables capturing many of the competing explanations of differential male and female occupational selection. Our results tell us that among jobs with similar physical, social, cognitive, risk and time demands, men and women select differentially into jobs that require different levels of visual, auditory and tactile perceptiveness, dexterity with the hands and 
fingers, and ability to visualize objects in space. Given the fact that neither employers nor employees may even be aware of male-female differences in these dimensions, we find it difficult to interpret these findings as being unrelated to differential job performance.

We attempt to push further on this issue for the gender difference in the sense of touch. As explained below, the female advantage in the sense of touch has been attributed to their smaller average hand/finger size — males and females with similar hand size have been found to have similar senses of touch. This suggests that shorter males should select into "touch jobs", which we identify with the DOT measure of feeling, as females do. Using measures of height as a proxy of hand/finger size, we cannot reject the hypothesis that this is true. This helps address the criticism that a female specific demand factor (e.g., employer discrimination) accounts for the relationship between feeling and sex differentiated occupational selection. We should also expect the relationship between sex differences in occupational selection and our feeling variable to be diminished once we directly control for occupational height differences. Again we show that controlling for males' average height across occupations reduces the estimated relevance of the DOT measure of feeling to occupational segregation. This suggests that any unobserved supply side variable confounding the results for this attribute must be correlated with height (hand size) rather than gender.

\section{Previous Literature on Occupational Segregation}

A large literature has documented the existence of gender based occupational segregation, and examined its trends over time (e.g., Blau Weiskoff 1972, Blau et al 2013 and the overview in Blau and Kahn 2000). Attempts to explain this segregation have focused on three classes of explanations. The first examines the role of differences in human capital or skills. A recent emphasis here is on the role of social skills. Bacolod and Blum (2010), Black and Spitz-Oener 
(2010) and Borghans et al. (2014) all argue that women's advantage in people skills (see also Gilligan, 2001), combined with an increasing return to social tasks, have contributed to the decline in the gender earnings gap over the past several decades. Levanon and Grusky (2016) also emphasize the contribution of sociability to segregation as well as physical factors. ${ }^{2}$ More comparable to our focus here is Bielby and Baron's (1986) investigation of the relationship between occupational segregation in a sample of firms in California in the 1960s and 70s and DOT skill measures. ${ }^{3}$ They conclude that neither the skills examined nor measures of turnover costs can account for the observed segregation.

A second class of explanations argues that occupational segregation is related to gender differences in preferences for job attributes. A major emphasis is on women's hypothesized preference for jobs that provide flexibility to accommodate family responsibilities. Polachek (1981) argued that women have an incentive to choose jobs in which they are penalized less for extended family leaves. More recently, Goldin (2014) has highlighted the linearity of the wage schedule with respect to hours worked as a measure of family-friendly professions. Another set of preference-based explanations emphasizes gender differences in preferences for risk, competition and prestige. ${ }^{4}$ Buser et al. (2014) show that men select into more prestigious academic tracks, conditional on ability. Several papers argue that a male preference for prestige and social comfort leads them to abandon occupations rapidly once they "tip" to being predominantly female (Akerlof and Kranton 2000, Goldin 2013, Pan 2015). Finally other signals

\footnotetext{
${ }^{2}$ Levanon and Grusky (2016) examine a number of the occupational characteristics examined here aggregated into composite measures.

${ }^{3}$ The basis for the hypothesized skill differences across genders is a contemporaneous summary of research on sex differences, primarily from psychology (Maccoby and Jacklin 1974).

${ }^{4}$ There is evidence showing that men seem to be less risk-averse (see reviews in Croson and Gneezy 2009 and Eckel and Grossman 2008), and are more responsive to competitive environments (Gneezy et al., 2003; Niederle and Vesterlund, 2007; see Cotton, McIntyre and Price, 2013 for a rebuttal of this evidence.), and a number of papers show that men are differentially likely to select into jobs that have higher earnings or mortality risk (Deleire and Levy, 2004; Leeth and Ruser, 2006; Bonin, 2007; Grazier and Sloane, 2008.).
} 
of gender differences in job/career preferences include that women are less likely than men to receive college degrees in STEM fields even conditional on math test scores (Weinberger 1999) and females' job satisfaction declines in the proportion of men in their occupation, conditional on other occupational attributes (Lordan and Pischke 2016).

A third class of explanations of occupational segregation explores the role of discrimination. Several papers using matched pairs of applicants or randomized resumes have found discrimination against female applicants in male-dominated jobs and against male applicants in female-dominated jobs (e.g., Riach and Reich, 2006; Riach and Reich, 2002 for a review of other papers with similar results.)

Our contribution relative to this literature is twofold. First, we extend research looking at the role of skills to gender differences in sensory, motor and spatial skills and explicitly consider our evidence in light of the research supporting these differences. Secondly, we simultaneously examine the contributions of a number of explanations of occupational segregation suggested in the literature together with our new skill measures. To the extent that we successfully capture the competing explanations with our choice of variables from the DOT and O*NET databases, this tells us something about the relative importance of different types of explanations.

Of course, the distinction between "skills", "preferences" and "discrimination” is somewhat artificial. If discrimination or social norms affect skill and preference formation, our results will also pick up the effect of these processes. While we consider this less likely for some of the sensory, motor and spatial skills that have stronger biological origins (for example, feeling or color discrimination), or are evident at very young ages, we do not rule out the possibility that discrimination contributes our results. Our analysis speaks to the potential role of realized skill differences between men and women in explaining occupational segregation; it does not tell us 
anything about the sources of these skill differences. It does, however, provide direction for future research in this area by identifying the skills that have the largest correlation quantitatively.

\section{Gender Differences in the Skills and Abilities}

Investigation of gender differences in skills and abilities is very active in many fields.

This research has spawned popular debate through books that both support and condemn a biological interpretation of the differences between males and females (e.g., Brizendine 2007, Fine 2010; McCarthy and Ball 2011).

While not our main concern here, explanations of gender differences fall into three general classes. The leading biological explanation, which is currently the focus of research in many fields, is prenatal exposure to hormones, and in particular androgens (see, for example Halpern 2012). Males have greater prenatal exposure to androgens, most significantly testosterone, and have higher levels of circulating testosterone post birth. The higher prenatal and postnatal exposure to androgens is hypothesized to have organizational impacts on the developing brain. For example, it is thought to accentuate functions that are controlled by parts of the brain that have relatively high numbers of androgen receptors. ${ }^{5}$ A second class of explanations is founded on evolutionary principles of natural selection and the traditional gender roles in hunter/gatherer societies. The hypothesis is that natural selection has favoured the reproduction of males with "hunting skills" and females with "gathering skills". ${ }^{6}$

The third class of explanations is that any gender differences are environmentally

\footnotetext{
${ }^{5}$ Evidence in favor of these theories is constructed by relating levels of prenatal androgens to specific skills. There are also investigations of the relative abilities of children who are exposed to greater levels of prenatal androgens than the norm-for example different sex dizygotic twins and children with congenital adrenal hyperplasia (CAH) and variation in abilities according to natural or synthetic variation in hormones (e.g., menstrual cycles and hormone replacement therapy).

${ }^{6}$ The support for this explanation is through interpretation of gender differences through this lens. For example, a male advantage in targeting distant objects reflects a hunter past, while a female advantage in fine motor skills echoes a foraging background.
} 
determined. Girls and boys are viewed as equally endowed, but they are subsequently exposed to different circumstances as a result of cultural norms and/or differential access to power. For example, males' affinity for things and females' affinity for people might be traced through a lifetime of dichotomous stimuli, perhaps starting with the truck/doll divide in childhood. ${ }^{7}$

While not strictly speaking an explanation, it is also important to note that another participant in this debate is the argument that the evidence does not support any gender differences in traits. The "gender similarities hypothesis", associated with Hyde (2005), maintains that based on meta analyses most effect sizes—-the standardized difference in meansof male/female differences are either close to zero or small (in general less than 0.35). ${ }^{8}$

Currently biological explanations attract much of the research and much of the controversy. Our analysis does not shine any new light on the origins of sex differences in skills and aptitudes. For our purposes, the more important consideration is whether any differences are present before occupational choices are made so they are not the result of learned occupational experience.

Finally, much of the criticism of the use of research on sex differences to explain everyday life is rooted in speculation of what the differences might mean versus speculation that effect sizes of certain magnitudes must not mean anything. We instead ask the empirical question of how occupational selection lines up with the researched sex differences, conditional on our mapping of the sex differences into DOT codes.

\section{Gender Differences in Sensory Functions}

\footnotetext{
${ }^{7}$ Unfortunately, simple documentation of gender differences in these environments does not provide much leverage to test this explanation. For example, Dickens and Flynn (2001) argue genes and environment are matched in ways to amplify what might initially be a modest genetic based difference. Absent controlled experiments, the primary leverage to test the environmental explanation is to discover whether gender differences in traits are present at very young ages before the effects of social environments can have much effect.

${ }^{8}$ Our focus is on sensory, motor and visiospatial gender differences that are mostly not covered in Hyde's evidence and/or are more generally regarded as areas in which gender differences do exist.
} 
Gender differences in some sensory functions have long been reported (Velle 1987). Certain differences have an explicit genetic origin, such as colour blindness. For others, the exact source is still under investigation, although they are well documented (see also Halpern 2012, 105-107 for an overview).

Vision-One dimension of gender differences in vision has a clear genetic source. The incidence of colour blindness is much higher in males than in females because the most prevalent forms (red/green) are a result of gene deletion or damage on the $\mathrm{X}$ chromosome. Because females have two $\mathrm{X}$ chromosomes and males have one, and color blindness is a recessive trait, this result of genetic abnormalities of this chromosome is more likely to be inherited by males.

While there is a large gender difference in the incidence of color blindness, the overall incidence is small enough that color blind individuals may be easily able to match with jobs that do not require color discrimination skills. Recent research, however, suggests that, within a sample of college students, females exhibit greater sensitivity to colour than males in populations with normal vision (Handa and McGivern 2015; Abramov et al. 2012b, Murray et al. 2012), while in a sample of 16-23 month old infants a higher proportion of females could distinguish colors (Mercer et al. 2014).

Research into gender differences in vision other than color blindness is relatively recent, and a proposed explanation is males' higher levels of androgen exposure. For example, adult males exhibit better visual acuity—sensitivity to fine detail and rapidly moving stimuli (Velle 1987, Abramov et al. 2012a). A suspected cause is the high number of testosterone receptors in the cerebral cortex. Environmental factors may also play a role, as there is evidence that vision acuity can be improved through training (Ward et al. 2008; also see Halpern, 2012). Finally, evolutionary explanations have also been forwarded based on the distinct gender roles in 
hunter/gatherer societies (Abramov et al. 2012a).

This same evolutionary hypothesis has led researchers to look for sex differences in the visual perception of near and far space. Recent research has provided evidence of the better accuracy of females in near space and of males in far space in a sample of young adults (Stancy and Turner 2010), and similar gender differences in puzzle solving (Sanders et al. 2007b). Hearing — Females have been observed to have a higher degree of auditory sensitivity than males (detecting weak sounds in quiet), especially at higher frequencies, starting in childhood (Halpern 2012, McFadden 1998, Velle 1987). Conversely, males have been observed to have a higher tolerance of noise, again starting in childhood (Velle 1987). Roughly speaking females have been found to experience a given noise level twice as strongly as males. Males are observed to have better abilities in sound localization, have a larger right ear advantage and be better at distinguishing signal sounds through masking sounds (McFadden 1998).

Among older populations environmental factors are thought to contribute to sex differences in hearing. However, these are less likely factors for differences found among children. One branch of current research is on the impact of androgens on the development of auditory function. For example, the higher exposure of males to androgens in the prenatal period is thought to weaken cochlear amplifiers. Males have weaker otoacoustic emissions than females, even at very young ages (McFadden 2002, McFadden 2008, Halpern 2012). Taste and Smell—Females have been observed to have a better sense of smell and taste. The documentation of sex differences in the sense of smell has a long history and is widely believed (see Brand and Millot 2001 for a survey). While sex differences have not been observed for the sensitivity to, or ability to, discriminate all smells, where they are detected they always indicate greater ability for females—Halpern (2012, p.106) reports that the advantage "extends across the 
entire lifespan”. Environmental explanations have been offered for these differences—females may have a larger learned experience with odours. However, evidence of sex differences at early ages and female superiority at identifying "male" odours suggests there are other factors at play. Candidates for explaining this difference are sex differences in anatomy, brain structure and/or function, evolutionary functions and gender differences in verbal ability. The evidence on sex differences in taste recognition and perception are more mixed suggesting females perceive some tastes better, but others not as well (Halpern 2012 107).

Touch —Finally, females have been observed to have a better sense of touch, a finding for both blind and sighted subjects and so distinct from sex differences in visual acuity (Halpern 2012). At least one dimension of this difference appears to be biological. Perception of textures is hypothesized to be related to the density of sense perceptors-Merkel cells—in the hand. Smaller fingers have a higher density of these cells. Therefore female's smaller stature and smaller finger size, on average, leads to their better perception of textures (Peters et al. 2009). Touch sensitivity has been found to be similar between men and women with similar finger size.

\section{Gender Differences in Perceptual Motor Tasks}

Motor Abilities-There is evidence of sex differences in some motor and visual coordination tasks. Tests of abilities for aiming at moving or stationary targets appear to favour males by a relatively large margin (Hall and Kimura 1995, Watson and Kimura 1991, but also see Auyeung et al 2011), while females demonstrate an advantage in fine motor dexterity (Nicholson and Kimura 1996). Tests of both these abilities find similar sex differences among young children (Sanders and Kadam 2001).

Common tests of these abilities have been criticised for conflating any sex differences in perceptions of near and far space with any sex differences in specific motor skills. Controlling 
for sex differences in space, Sanders et al. (2007a) present evidence that females perform better in finger tasks while males perform better in arm tasks.

Recent research takes up this distinction between a gross motor movement advantage for males and a fine motor movement advantage for females (see Sanders 2013 for an overview). For example, females have an advantage in movements of the wrist and fingers (Sanders and Walsh 2007, Sanders and Perez 2007). Finally, a male advantage has also been observed for tests of reaction time and finger tapping (Roivainen 2011).

The origins of these differences have not been isolated but evolutionary and (because this skill can improve with practice) environmental sources are possibilities. Prenatal testosterone exposure may also play a role as the 2D:4D digit ratio appears to predict targeting performance (Falter et al. 2006). Sanders (2013) cites recent evidence that hand and arm muscle manipulation are controlled by the brain's primary motor cortex via different "tracts" and there is recent evidence of sex differences in the regions of the brain associated with motor control. Perceptual Motor Tasks—Sex differences in some perceptual motor tasks, especially those involving digits and alphabets, appear to favour females (e.g., Roivainen 2011). These include perceptual speed, fine motor manipulations and tactile skills. For example, females have an advantage in the "Digit Symbol" task (formerly part of the Wechsler Scales) but not the “Inspection Time” task (Halpern 2012, Burns and Nettelbeck 2005). A female advantage in the Processing Speed Index of the Wechsler scales has been reliably found in a sample of primary and secondary school aged children (Longman et al. 2007).

Some of these differences are again attributed to females' smaller stature, on averagefemales’ smaller hand size on average might contribute to their advantage in fine motor tasks (Peters et al. 1990 and Peters and Compagnaro 1996). 


\section{Gender Differences in Visiospatial Abilities}

Sex differences in visiospatial abilities have been widely documented and in general favour males. The advantage is not uniform, however. Halpern (2012) in her review reports a male advantage in spatial perception, mental rotation, spatiotemporal ability, and to a lesser extent, spatial visualization. The evidence for abilities related to the generation and maintenance of a spatial image are mixed. Females have an advantage in remembering the spatial location of objects in an array (Sanders 2013). ${ }^{9}$ There is evidence that the gender difference in some of these abilities emerges at very young ages (e.g., Moore and Johnson 2008, Quinn and Liben 2008). Among high school seniors, Baker and Cornelson (2016) report a gender gap in a test of three dimensional mental rotation favouring males of 0.388 of standard deviation in 1960 and 0.253 of a standard deviation in $1980 .{ }^{10}$

Recent research emphasizes that in summarising this literature it is important to consider variation in the difficulty of the skill test across studies and the possible conflation of different skills within a single test. For example, Sanders (2013) argues that the evidence indicates a strong male advantage in coincidence-anticipation timing (CAT_-for example, the ability to predict when a projectile weapon will reach a moving target), in children and adults, predominately in easier rather than harder CAT tasks. CAT skills are useful for activities such as sports and driving. Also, as noted above common tests of targeting and motor abilities potentially conflate sex differences in motor functions and sex differences in perceptions of near and far space. Sanders (2013) reports that there is good evidence of a male advantage in the processing of far space and a female advantage in the processing of near space, although there are also some anomalous studies.

\footnotetext{
${ }^{9}$ Newcombe (2010) provides the evidence against this claimed female advantage.

${ }^{10}$ For 1960 they report a gender gap, controlling for age, of 0.275 standard deviations for high school freshman and 0.415 for high school seniors.
} 
An androgen based explanation of male advantage in visual spatial skills has been forwarded based, for example, on higher spatial performance of females with congenital adrenal hyperplasia (Miller and Halpern 2014). Sanders (2013) notes that near and far space are processed by different mechanisms in the brain, setting the stage for sex differences in the development of these mechanisms to be important. However, there is also evidence that measures of the gender difference in spatial abilities vary across countries according to some measures of socio-economic development, although not always in expected ways (e.g., Lippa et al. 2008). In addition, there is evidence that mastery of spatial skills is responsive to training (e.g., Miller and Halpern 2013, Hyde 2014). Finally, because there is no explicit training in visual spatial skills in schools, the sex difference may reflect gender differences in extracurricular activities such as participation in sports and computer use (e.g., Cherney and Voyer 2010).

\section{Data and Empirical Framework}

\section{Occupational Characteristics Data}

To link the sex differences documented in the last section to occupational segregation, we use information on occupational skill requirements taken from the 1977 and 1991 editions of the DOT. The DOT, first published in 1939, was originally intended to help match workers with appropriate jobs. It rates each of several thousand occupations along a number of dimensions such as aptitudes, temperaments, interests and physical demands. In Table AI of the appendix, we describe the DOT measures that we believe are most closely linked to the sensory, motor and spatial aptitudes that consistently show sex differences, as outlined in the previous section.

The DOT measures were not derived with the intent to measure the same skills and aptitudes in which researchers have documented sex differences. Our mapping, as summarized 
by our hypotheses of expected signs of any male/female sex difference, is necessarily rough.

A couple of comments are warranted before proceeding. First, the evidence for sex differences in the senses of taste and smell are at best mixed, and the explanations include corresponding sex differences in lived experience. This leads to the possibility that the sex segregation in occupations due to some other factor leads to the measured sex differences in the senses of taste and smell.

Second, as noted above, a way to organize the sex differences in motor skills is in the categories of fine and gross motor skills. Many of the skills and aptitudes with a documented female advantage are considered fine motor skills and, as Halpern (2012) observes, many studies support such a generalization. The DOT categories of fingering, finger dexterity, handling and motor coordination — the ability to coordinate eyes and hands or fingers with speed and accuracy—are more clearly associated with this category. Eye-hand-foot coordination—the coordination of hands and feet with visual stimulae —-we view to involve arm and leg coordination which are gross motor abilities. Clerical perception—-the ability to perceive details in tabular or verbal input—has been long associated with the female advantage in perceptual motor skills, but also, controversially, has been used to argue females are better suited for clerical jobs. Finally, we are agnostic about the coding of manual dexterity, which involves working with both arms (a male advantage) and hands (a female advantage). ${ }^{11}$

To assess the importance of sensory, motor and spatial skills relative to other explanations of occupational gender segregation, we also attempt to capture an occupation's i) overall physical demands, ii) math and verbal skill requirements, iii) people/things orientation,

\footnotetext{
${ }^{11}$ We do not make use of the DOT physical demand codes kneeling, climbing, balancing, stooping, crouching, crawling, talking and reaching. We also exclude the aptitude form perception (the ability to perceive pertinent detail in pictures and graphs) and the physical demands accommodation (the adjustment of the eye to bring things into focus), and field of vision.
} 
iv) degree of risk and competitiveness and v) time flexibility. As outlined above, all of these factors may be related to men and women's occupational choices.

We capture an occupation's physical demands using the DOT variable "physical strength”. Physical strength represents a relatively uncontroversial and well-understood gender skill difference; as such, this variable provides a useful benchmark for evaluating the impact of other skills. For math and verbal demands, we use the DOT General Educational Development scales for math and language, respectively. We note females are widely viewed as having an advantage in verbal skills, while a hypothesized male advantage in math skills attracts much debate. Our measures of people/things orientation are the DOT variables "Temperament dealing with people" and "Interests - working with things". ${ }^{12}$

To capture an occupation's degree of risk and competitiveness, we use three measures. For risk, we include an occupation's mortality rate, derived from the Bureau of Labor Statistic's Census of Fatal Occupational Injuries. ${ }^{13}$ To measure competition, we use the work context variable "level of competition" from the O*NET database. O*NET, produced by the U.S. Department of Labor, has supplanted the DOT in recent years, and provides many similar measures of occupational requirements as well as some additional characteristics. Finally, to capture the fact that competitiveness may lead men to be more sensitive to prestige, we also include the occupational prestige score proposed by Nakao and Treas (1994). This is based on data from the 1989 General Social Survey, in which respondents were asked to rank occupations on scale of social standing from 1 to $9 .{ }^{14}$

\footnotetext{
${ }^{12}$ As shown in the robustness table in the Appendix, alternative measures of social demands produce similar results. ${ }^{13}$ We use information on the number of fatalities for each occupation in 2012, and convert this to a mortality rate using employment information. The earliest fatalities data are from 1992. Because these data are provided for different occupational codes, however, we can only match them to 431 Census 2000 occupations (as opposed to the 468 used in our main analysis.) The results are similar if we use the 1992 fatalities information for our 1970 analysis.

${ }^{14}$ While the initial scores were based on the 1990 Census occupational coding, we obtain the measures for the 2000
} 
For measures of time flexibility, we use Goldin’s (2014) proposed measures from O*NET. Goldin (2014) argues that non-linearity of wage/work locus helps explain the scarcity of females in high work, high wage jobs. This non-linearity in turn is affected by an occupation's time demands, the degree to which it requires structured versus unstructured work, the freedom its employees have to make decisions, and the extent to which it requires contact with others and the maintenance of interpersonal relationships. Because we use other measures of an occupation's interpersonal demands, we use only the first three suggested O*NET measures (the O*NET characteristics “time pressure”, "structured vs. unstructured work” and "freedom to make decisions”) as our measures of time flexibility. The coefficients on all three variables are expected to be positive. ${ }^{15}$

\section{Occupations}

We link the DOT measures and the other occupational characteristics to occupations in the decennial Censuses from 1970-2000, and the 2012 3-year American Community Survey (denoted as 2012). We use the crosswalk developed by Blau et al. (2013) to convert occupations in the earlier Census years and the ACS to the 2000 Census occupational coding (see details in the Data appendix.)

The DOT uses an internal coding system, but the 1977 data are also linked to a CPS file that provides 1970 Census occupational codes. We use these to match both 1991 and 1977 DOT codes to 2000 Census occupations. In this way, we were able to link DOT ratings to 476 of the 505 Census occupational codes. (See the Data appendix for a further description of this process.) Because the DOT contains more detail than the Census occupation coding scheme (so that each Census code contains a number of DOT occupations), we average the ratings across all DOT

Census occupational coding using data from IPUMS (Ruggles et al., 2010).

${ }^{15}$ Note that the "structure" variable is reverse-coded in the O*NET, with higher values indicating more freedom for the worker to determine tasks, priorities and goals. 
occupations within a Census code, with weights corresponding to that occupation's share of employment. This means that, although most of our DOT measures are categorical, they are continuous within our data. When possible, we assign occupations their 1977 DOT measures for the 1970 and 1980 Censuses, and the 1991 DOT measures thereafter. This is not possible with the physical demands ${ }^{16}$ and certain environmental conditions, however, which are only available in 1991; for these measures, we use the 1991 measures for all years.

Both the O*NET measures and the fatality information from the Census of Fatal Injuries are provided at the SOC occupation level. To convert these measures to Census 2000 occupational codes, we use a crosswalk provided by the U.S. Census Bureau. We were able to link O*NET measures to 468 Census occupations (all of which also have fatalities information), which provide the final sample of occupations for our analysis. These occupations account for 98.4\% of the U.S. workforce in 2012, and have a Duncan index that is nearly identical to the Duncan index for the U.S. workforce as a whole.

\section{Empirical Framework}

Our objective is to estimate Duncan indices of gender occupational segregation net of any gender occupational selection on occupational differences in the DOT sensory, motor and spatial attributes. The Duncan index is defined as

$$
D=(0.5) \cdot \sum_{j}\left|m_{j}-f_{j}\right|
$$

where $f_{j}$ is the fraction of all employed women who work in occupation $j$ and $\boldsymbol{m}_{j}$ is the fraction of all employed men who work in occupation $j$. The index, which ranges between 0 and 1 , is commonly interpreted to indicate the proportion of women or men who would need to change occupations if the occupational distribution of men and women were to be the same.

\footnotetext{
${ }^{16}$ Excepting physical strength, which is available in both years.
} 
We start by estimating the relationship between our occupational attribute measures and the relative probability that men and women select into an occupation. Specifically, we regress the log odds of male to female employment in an occupation

$$
l_{j}=\ln \left(\frac{\frac{m_{j}}{\left(1-m_{j}\right)}}{\frac{f_{j}}{\left(1-f_{j}\right)}}\right)
$$

on our measures of occupational characteristics. The term $f_{j} /\left(1-f_{j}\right)$ represents the odds that a randomly selected, employed female works in occupation $j$. The ratio of these odds for men and women tells us about the relative likelihood that men and women select into occupation $j .{ }^{17}$

Our main regression equation is:

$$
l_{j}=\alpha+\beta S_{j}+\varepsilon_{j}
$$

where $S_{j}$ are measures of the characteristics of occupation $j$.

We use the results of estimating (2) to simulate the effect of removing any differential selection on skills across occupations. We first predict the log odds for each occupation that would occur if a particular set of occupational characteristics did not differentially affect the occupation choices of men and women. Let $S_{k}$ denote a subset of occupational characteristics, and $S_{-k}$ denote all of the remaining occupational characteristics. The predicted log odds for occupation $j$, eliminating differential gender selection on the characteristic set $k$ are:

$$
\hat{l}_{j}=\hat{\alpha}+\hat{\beta}_{-k} S_{-k}+\hat{\varepsilon}_{j}
$$

Next, we find the unique occupational shares, $\hat{f}_{j}$ and $\hat{\boldsymbol{m}}_{j}$, that solve these log odds and also keep each occupation's total share of employment at its actual level (this yields 936 equations in 936

\footnotetext{
${ }^{17}$ Alternatively, we can write the odds ratio as the male-to-female ratio in occupation $j$ over the male-to-female ratio in all other occupations. If $j$ is small relative to the labor market, this denominator of this equation is approximately equal to the male-to-female ratio of total employment. The odds ratio therefore tells us about how far the sex ratio in an occupation deviates from the norm for the labor market.
} 
unknowns). ${ }^{18}$ Finally, we construct Duncan indices from these predicted shares.

In order to evaluate whether these predicted indices are significantly different from the actual Duncan index in each year, we compare them to a distribution of Duncan indices constructed from 500 rounds of resampling from the actual data. They tell us the probability of observing the given level of the Duncan index in an economy that actually had the same underlying selection behaviour as the actual economy. Because the sample size is large, this procedure produces bounds that are quite narrow: the resampled Duncan indices vary from the actual Duncan index only at the fourth decimal point. As a result, all of our estimated Duncan indices are significantly different from the actual Duncan index at the 1 percent level. We therefore omit the standard indications of significance from the tables showing the simulated Duncan indices.

\section{Regression Results}

\section{An Overview of Gender Occupational Segregation}

In table 1 we report estimates of the Duncan index of occupational gender by census year and for 2012 based on ACS data. While the estimates differ slightly in magnitudes from those in Blau et al. (2013), they tell the same story. The change in the Duncan index between 1970 and 1990 is more than 10 percentage points, while in the next 22 years it is less than 4 percentage points. In 2012 just over half of men or women would need to change occupations for the occupational distribution of males and females to be the same.

In the next five next rows we list the five occupations that make the largest contributions to the Duncan index in each year. They are very stable over time-secretaries and administrative

\footnotetext{
18 This procedure produces occupation shares $m_{j}$ and $f_{j}$ that do not add up to one, which is a problem for the interpretation of the Duncan index. We solve this problem by rescaling so that the shares do add up to one, i.e. by allowing the total number of men and women in the labor market to change. In practice, the changes in the total size of the labor force are fairly small - about $3 \%$ for men and $1 \%$ for women.
} 
assistants make the largest contribution in every year. Registered nurses and bookkeeping clerks appear in four of the five years. In the seventh row we report the proportion of the Duncan index contributed by these top five occupations. It declines gradually from 21 percent to around 17 percent over the period. This is an initial indication that quantitatively the Duncan index is relatively concentrated in few occupations, as there are 505 occupational categories in each year. ${ }^{19}$

A recent focus of economic research on occupational segregation is STEM occupations. While there are many reasons to focus on these occupations, their contribution to overall gender employment segregation is not one of them. In the next row we report for each year the proportion of the Duncan index represented by segregation in these occupations. It is quite steady averaging ranges from about $4 \%$ at the beginning of the sample to $5 \%$ in $2012 .{ }^{20}$

In the final rows of table 1, we report the total number of occupational categories with positive employment in each year, and indicators of the importance of the occupations making the largest contributions to the Duncan index to overall gender segregation. For example, just 25-30 occupations in each year, or just 6 percent of the total number, can account for 50 percent of the Duncan index. There are no STEM occupations in this group, and in 2012 they represented over 29 percent of male employment and 45 percent of female employment. In each year roughly 170 of 505 occupations can account for 90 percent of the Duncan. These results amplify the message of the top 5 occupations. Gender occupational segregation is a story that is concentrated in a relatively small number of occupations.

\section{Gender occupational selection on aptitudes}

\footnotetext{
${ }^{19}$ In Table 1, we report results for all 505 Census occupation categories. Once we move to the analysis of skills, we will be restricted to the 468 occupations that can be matched to DOT codes. This makes very little difference: the Duncan index for our 468 occupations is 0.644 in 1970 (the same as when we use the full set of occupations) and 0.508 in 2012 (versus 0.506 for all occupations.)

${ }^{20}$ Our definition of STEM jobs is from the U.S. Department of Commerce (2011).
} 
In Table 2, we present the results of univariate regressions individually relating the variables capturing more traditional explanations of gender segregation to the log odds of male employment. The first row shows a coefficient from a regression of the log odds of male employment on the DOT variable for physical strength. All occupational attributes are normalized to have mean 0 and standard deviation one, so the estimates are interpreted as the change in the log odds associated with a one standard deviation increase in a skill. As expected, occupations with higher demands for physical strength have higher log odds, indicating that there are more men in these occupations. This effect is substantial: a one standard deviation increase in the physical strength measure is associated with a 0.723 increase in the log odds of male employment in 1970 and a 0.996 increase in 2012. In 2012 the odds ratio is just over 2.7 in an occupation one standard deviation above the mean in physical strength. The DOT physical strength variable alone accounts for $14 \%$ of the variation in the log odds in 1970 , and $32 \%$ in 2012.

In the next row, we show corresponding results for "GED - language" and "GED math”, which are intended to capture men's hypothesized disadvantage in verbal skills and advantage in math. The math variable significantly predicts a higher male share in 1970, but a lower male share in 2012, while the language variable predicts a higher female share in 2012. However, these variables account for a smaller proportion of the variation in the data with $\mathrm{R}^{2} \mathrm{~s}$ of $1.5 \%-8.0 \%$. In the next two rows, we examine the effect of variables corresponding to the people/things dichotomy. These variables have a strong and significant relationship to the log odds, in the expected directions: occupations requiring a temperament for dealing with people have more females, while occupations requiring an interest in working with things have more men. The variables relating to mortality risk, competitiveness and prestige are all strongly related 
to the log odds in the expected direction, with the $\mathrm{R}^{2}$ ranging from $2-11 \%$. In the final rows are the time flexibility measures proposed by Goldin (2014). As hypothesized, occupations with high time pressures and more freedom to make decisions tend to have relatively more males in them (although the second relationship is significant only in 1970.) However, occupations that are relatively less structured have significantly fewer men in 2012. The $\mathrm{R}^{2} \mathrm{~s}$ for each these variables are relatively small. ${ }^{21}$

In Table 3, are the corresponding univariate results for the sensory, motor and spatial aptitudes. In the first panel are the estimates for the sensory skills—color vision, visual acuity, auditory sensitivity, the sense of taste and smell and feeling. The results for color vision and color discrimination are not of the expected sign, while the estimates for the remaining skills are. Larger estimates are observed for far acuity and the two measures of auditory sensitivity. The noise attribute alone can account for $44 \%$ of the variation in the data in 2012, and the estimated association with the log odds ratio for this attribute in each year is larger than the estimate for physical strength.

Estimates for the motor skills are presented in the next panel. Here most of the estimates are of the expected sign, with the exception of motor coordination and handling in 2012. As noted above, the manual dexterity attribute involves both arms and hands and thus we do not have a definitive prediction of a sign for the effect. The result here indicates a positive association with male employment.

In the final panel are the results for spatial attributes. For both measures of spatial perception, the estimates are right signed and very large -in fact, typically larger than the

\footnotetext{
${ }^{21}$ Note however that a variable may have a high $\mathrm{R}^{2}$ in predicting the log odds across occupations, but very little aggregate effect on the Duncan index if either the skill does not vary substantially across occupations, or if its variation is primarily concentrated in very small occupations (which are weighted equally with large occupations in the log odds regressions.)
} 
estimated coefficient on physical strength. The estimate for spatial skills falls by about $1 / 4$ from 1970 to 2012; the coefficient on depth perception, however, increases slightly over this time period. By 2012, this single skill measure can account for $42 \%$ of the variation in log odds ratio. The fact that a few of the estimated coefficients are of the wrong sign in Tables 2 and 3 might be explained by the fact that occupational characteristics are not independent of one another. Men may work in jobs that are more reliant on color vision, for example, because these jobs also demand aptitudes for which they are relatively advantaged, or because these jobs have other characteristics that men tend to value more than women. To understand the relationship between occupational characteristics and the log odds, conditional on overall occupational characteristics, we next present results based on a full model in which all attributes are included simultaneously.

The results of these regressions are shown in Table 4 . The statistically significant estimates from these regressions are now all of the expected sign, with one exception (eye-handfoot coordination, although this is relatively unimportant quantitatively.) Among the sensory attributes, noise and feeling are the strongest and most significant predictors of the log odds. The role of the individual motor skill is less in this specification, especially in 2012. Both of the spatial measures are strongly and significantly related to the log odds of male employment in both years. Among the variables capturing competing hypotheses, the significant predictors of the log odds are physical strength, GED - math, interest in working with things, the level of competition and freedom to make decisions. Comparing the partial $\mathrm{R}^{2} \mathrm{~s}$ of these variables indicates that spatial aptitude is the strongest predictor of the log odds in 1970, followed closely by things orientation. Physical strength and GED - math are also strongly related to the log odds. In 2012, the strongest predictor is competition, following by feeling, noise and physical strength. 
The spatial variables also have a strong relationship to the log odds.

In the appendix we report how the results change in a series of robustness checks. These include adding the ratio of male to female wages and average weekly hours ${ }^{22}$ at the occupational level as additional occupational attributes, omitting nominally duplicate skill measures (e.g., color vision and color discrimination) and investigating alternative DOT measures of people skills. Each of these modifications has little impact on the inference. We also estimate models that use either only the 1970 or 1991 DOT definitions for both the 1970 and 2012 data, which lead to minor changes in inference for one or two attributes. Finally, we have calculated the log odds ratio separately for the age groups 18-24, 25-34 and 35-64 and estimated the pooled regression testing for interaction effects between dummy variables for the younger age groups and the DOT aptitude measures. The estimates of these interactions for both age groups and in both years are uniformly statistically insignificant.

The message of this analysis is that estimated relationships between the male to female log odds ratio and the DOT measures of sensory, motor and spatial aptitudes are largely the sign predicted by the cited research on sex differences. In the more comprehensive specification, multicollinearity is a challenge to isolating the relationships for individual skills. ${ }^{23}$ The estimates for the attributes/skills of noise, feeling, spatial and depth perception stand out as making an empirically unique contribution to the log odds employment ratio, on a similar scale to the contributions of physical strength, GED—math, interest in things and competition. The

\footnotetext{
${ }^{22}$ Weekly hours are provided in intervals in the 1970 Census data; we use the midpoint of each interval to impute weekly hours.

${ }^{23}$ We have estimated the models reported in table 4 using the shrinkage estimator Least Absolute Shrinkage and Selection Operator (LASSO). For 1970, the estimates from this method are zero for color vision, manual dexterity and motor coordination. For 2012 the estimates are zero for color vision, near acuity, hearing, manual dexterity, motor coordination and eye-hand-foot coordination. For both years, the estimates for noise, feeling, handling and the spatial measures are mostly modestly smaller that in table 4 . These results are available from the authors on request.
} 
analogues of these DOT skills in the research literature- hearing, touch and spatial perceptionare among the least controversial and widely acknowledged sex differences, and ones that have been documented at young ages.

\section{Omitted Variables: The Case of Feeling}

As noted in the introduction, omitted variables potentially confound our inference. On one hand, our DOT variables predicting, say, female employment may instead be proxies for demand side factors such as employer discrimination that segregate females into certain occupations. On the other, unobserved supply side factors correlated with our DOT measures may be the true determinants of female or male employment. Similar challenges are faced in the growing literature on the hypothesized social skills of females (and things orientation of males) and are ultimately not resolved absent some random variation in the aptitude of interest. Furthermore, even with random design it is uncertain whether the resulting variation has external validity for the empirical difference in a given aptitude across the sexes.

The sex differences we focus on are founded on a substantial body of academic research. Furthermore, in general the sign pattern in our estimates match the predictions of whether certain skills should correlate with relative male of female employment from this literature. This provides some confidence that the regularities we identify are legitimate (or perhaps as legitimate as the relationships of gender based occupational segregation to social skills, physical strength etc.).

This said, because the gender difference in the sense of touch is thought to be a function of finger size (which in turn is correlated with gender) rather than a function of gender per se, this aptitude provides an opportunity to make some progress on this issue. First, if the sense of touch is a function of finger size and not gender, then finger size should predict the occupational 
choices of males as it does females. This "test" therefore helps us rule out a hypothesis that a measure of touch is a proxy for some gender specific demand side factor, for example employer discrimination, which instead determines occupational choice. Second, a measure of hand size should substantively diminish the correlation of touch with occupational segregation. Such evidence again helps address a gender specific supply side confounding unobserved variable.

Our measure of touch is the DOT variable "feeling". As documented in table 4 this aptitude is a significant correlate of relative female employment. We are not aware of a representative data set that provides measures of finger or hand size. However, the National Health Interview Survey (NHIS) provides measures of respondents' heights and of their occupational choices. A number of studies document that finger size and hand size and height are positively correlated (e.g., Garrett 1971, Guerra et al. 2014, Suseelamma 2014).

Our first approach to evaluating whether our feeling variable is actually picking a sex difference in touch rather than some other effect is to directly add a measure of height to the log odds regressions. To do this we calculate average height by occupation using the 1990-1994 NHIS. ${ }^{24}$ Because males are taller on average than females, using both males and females to calculate the averages would produce a variable that would capture both any shorter stature of workers in a particular occupation but also the greater presence of females. Since it is the former effect we which to isolate we use only the male sample to calculate the averages. Therefore, we will capture any tendency of males to sort into certain occupations on their height. We view this choice as providing a lower bound of any effect of height on the choice of occupations where small stature is an advantage because males may be limited in their ability to sort into these occupations due to their larger heights throughout the distribution. Also, to the extent that this

\footnotetext{
${ }^{24}$ The 1994 NHIS is the latest NHIS sample that contains information on height and has sufficiently detailed occupational coding to be useful for our analysis.
} 
measure of height has traction it demonstrates that our feeling variable is unlikely to be picking up a gender specific demand effect.

We note that height may proxy for other attributes in addition to smaller hands. Perhaps best known is its demonstrated correlation with cognition and non-cognitive skills (e.g., Persico et al. 2004, Case and Paxson 2008, Lundborg et al. 2014). We directly control for the cognitive demands of occupations through the DOT GED variables, and for non-cognitive skills to the extent that they are related with working with people, and so it is of interest how our measure of height impacts the estimates for these variables.

The results of adding this measure of average male height by occupation to our log odds regressions for 1970 and 20012 are reported in the first two panels of table 5. We report three specifications: 1) a univariate regression in which the DOT feeling measure is the only control (comparable to table 3), 2) a specification where we add the DOT/O*NET variables for the competing accounts of occupational segregation (physical strength, people/things, etc.) but not the other DOT variables for sensory, motor and spatial skills, and 3) a specification in which all skills are added (comparable to table 4). In 1970, adding the control for male heights has a substantive impact on the magnitude of the estimate for feeling. It falls in magnitude by 20 to 65 percent, depending on the specification. In 2012 the impact is more muted as the reduction in the estimate for feeling is between 6 and 19 percent. In the final panel we report results using the 1990 census to facilitate the next part for of the analysis. They more closely match the results for 2012.

It is interesting to note that the control for height has little impact on the estimates for GED math, GED language or dealing with people. Using the most complete specification (3) as a reference, the estimates for GED language are more often statistically insignificant than not. For 
GED math the estimate increases after conditioning on height, by 4 percent in 1970, by 7 percent in 2012 and by 8.5 percent for 1990. For the temperament working with people, the estimates are always statistically insignificant, and the change is roughly 1 percent in each year. Therefore, height appears to have minimal impact on our controls for cognitive and non cognitive skills.

The preceding analysis shows that male average height helps account for the negative relationship between feeling demands and relative male to female selection into a job. We next show directly that i) tall individuals select differently into jobs on the basis of feeling demands, and that ii) this selection process is similar for men and women. Using the same NHIS sample, we run a logit regression of the probability that individual $i$ is observed in occupation $j$ on the height of individual $i$, the skill demands of job $j$, the interaction between height and all skill demands, and a set of individual-level controls (age, race and education.) An observation in this regression is an individual by job interaction, with the dependent variable equal to 1 for the job that the individual actually occupies, and 0 for all other occupations. In principle, this requires approximately 472 x 250,000 observations (472 occupations times the number of individuals in the NHIS.) For computational ease, we instead take a random sample of 5 occupations that the individual does not work in, and add them to the occupation that the individual does work in, for a total of 6 observations per person. McFadden (1978) outlines the conditions in which this sampling of the "option set" results in consistent estimates. The coefficient on the interaction between "height" and "feeling" in this regression tells us whether taller individuals are more or less likely to select into jobs with a higher feeling rating. We perform this exercise separately for men and women.

The results of this exercise are reported in table 6 for males and females separately. They indicate that both males and females select into feeling occupations on height and in a very 
similar way. We cannot reject the hypothesis that the male and female estimates are the same.

The estimates for interactions of height with many of the other aptitudes and skills are statistically insignificant. Exceptions include clerical dexterity, which as noted above has a stature dimension, the spatial measures, which recent research has documented some association with height (Zhou et al. 2016), and the time structure variables and competition, which may reflect non cognitive skills.

In the next step, we use the estimates from the logit equations to predict the male occupational distribution that would occur if males had the same height distribution as females, but selected on the basis of height and job skill demands in the way they do currently. Specifically, we adjust the number of men in each occupation by the amount

$$
\begin{aligned}
& \Delta^{m}=\sum_{H} \operatorname{Pr}^{m}(j o b=j \mid h=H, x=X) \cdot \operatorname{Pr}^{m}(x=X \mid h=H) \cdot \operatorname{Pr}^{m}(h=H)- \\
& \sum_{H} \operatorname{Pr}^{m}(j o b=j \mid h=H, x=X) \cdot \operatorname{Pr}^{m}(x=X \mid h=H) \cdot \operatorname{Pr}^{f}(h=H)
\end{aligned}
$$

where $h$ represents an individual's height and $x$ represents the vector of individual covariates, and the summation sign is over all values of height observed for women. The first term represents the predicted number of men in each occupation, based on the logit model's results; the second term represents the number of men that would be predicted to be in each occupation if men selected on the basis of height the way they currently do, but had the female height distribution. The difference between the two represents the change that would occur if we shifted men to the same height distribution as women. We use the predicted number of men (the actual number plus $\Delta^{m}$ from (4)) and the actual number of women to calculate predicted log odds, and then substitute them as the dependent variable in (2).

In the first column of table 7 are estimates of the multivariate version of (2) using the 
1990 census. ${ }^{25}$ This is the census that temporally matches our NHIS data. The estimates are largely consistent with the multivariate estimates for 2012 in table 4 . In the second column are the results of estimating a similar regression using the 1990-94 NHIS data. These results are largely consistent with those in the first column demonstrating that our inference is not affected by using the NHIS. In the third column we present estimates for a restricted set of occupations using the NHIS. This is because our predicted log odds procedure results in negative predicted values of men in some occupations, and we drop these occupations from our analysis. As can be seen, there are no major changes in the estimates from focusing on this smaller set of occupations.

Finally in the last column of the table are the estimates using the predicted log odds. For DOT feeling variable the result is a substantively diminished correlation with relative female employment. This suggests that the estimates for feeling in columns 1 through 3 are substantially picking up an effect of being shorter rather than an effect of some other attribute of being female.

On balance we interpret the results in tables 5-7 as casting doubt that some gender specific demand side factor, such as employer discrimination, lies between the relationship between feeling and the log odds of employment. They also suggest that any unobserved supply side variable that accounts for a significant part of the feeling impact must be correlated with a worker's height rather than their gender.

\section{The Association of Gender Occupational Selection on Aptitudes with Gender Occupational Segregation}

The preceding evidence indicates that males and females select into occupations in ways

\footnotetext{
${ }^{25}$ For these regressions, we switch to the 1990 Census occupational codes, which is the coding available in the NHIS. There are 472 occupations with non missing log odds in the NHIS data; as a result, we limit analysis to these occupations
} 
consistent with research on sex differences in sensory, motor and spatial abilities. We next ask whether this selection has any quantitatively meaningful implication for the occupational segregation we observe in the labor market?

In tables 8 and 9, we provide estimates of adjusted Duncan indices following equation (3). These estimates remove the impact of any sex difference in occupational selection on the indicated attribute, all else equal. Table 8 shows the Duncan indices constructed in this way from univariate regressions (tables 2 and 3), while Table 9 shows the effect of eliminating different groups of occupational attributes based on the multivariate regressions (table 4). Because of the possibility of omitted variables bias in the underlying regressions we view the results as telling us more about the relative importance of various attributes than their absolute importance.

From an economic standpoint, the changes induced by individually removing the influence of many of the skills is quite small. For 1970 over the sensory and motor attributes the predicted Duncan indices range from 0.610 to 0.651 , representing changes of no more than $5.5 \%$ from the actual Duncan index in that year. In 2012, some of these attributes have a larger effect: eliminating selection on hearing, noise, eye-hand-foot coordination or clerical perception would reduce the Duncan index by $7-12 \%$.

The spatial attributes have more traction. The predicted Duncan removing the gender differential in selection on depth perception (which has the more significant effect) is $10.4 \%$ lower than the actual Duncan in 1970, and 16.1\% lower than the actual in 2012.

Among variables capturing the competing accounts, physical strength and competition have the largest effect on the Duncan index in 1970, each reducing the index by around 5\%. In 2012, physical strength, the temperament for dealing with people and mortality risk have the largest effect, in the 4-6\% range. 
Table 9 shows the results from eliminating the impact of selection on different groups of skills based on the regressions in table 4 . The impact of eliminating skill selection in groups is much larger than in the univariate results. In 1970, the effect of eliminating selection on sensory and motor skills is to reduce the Duncan by $4.2 \%$ and $5.1 \%$ respectively; the effect of eliminating selection on spatial skills is higher, at $10.9 \%$. In 2012, eliminating selection on sensory skills would reduce the Duncan by 7.1\%, while eliminating selection on motor skills is 3.3\%. Again, spatial skills are quantitatively more important, with a predicted reduction of around $10.4 \%$. In total, eliminating selection on sensory, motor and spatial skills would reduce the Duncan by $20.8 \%$ in 1970 , and $22.6 \%$ in 2012.

The effect of eliminating selection on the variables representing the alternative hypotheses is generally smaller in 1970, ranging from 1.9-3.4\%. In total, eliminating selection on these variables controls would reduce the Duncan index by $14.4 \%$. In 2012, the impacts of the different groups ranges from $0-6.3 \%$, with a combined effect of $18.3 \%$.

Eliminating selection on all of the occupational attribute measures reduces the Duncan index to 0.420 in 1970 (a 34.8\% reduction) and 0.299 in 2012 (a 41.1\% reduction.) Selection on observable occupation attributes therefore accounts for a large portion of occupational segregation, although the majority of the Duncan index remains “unexplained”, 2627

\footnotetext{
${ }^{26}$ The association between the aptitudes we consider and gender based occupational segregation appears fairly constant over time. Estimating adjusted Duncan indices by the age groups 15-24, 25-34 and 35-64 (using the 388 occupations with positive employment for both males and females among all cohorts), we find the relative importance of the sensory, motor and spatial skills remains relatively constant with age, ranging from $16-20 \%$ in 1970 and $19-25 \%$ in 2012. The effect of the variable representing the alternative accounts, in contrast, diminishes substantially with age. Eliminating selection on these variables reduces the Duncan index by $22 \%$ and $28 \%$ for the youngest age group in 1970 and 2012, respectively; for the oldest age group, these effects are $11.4 \%$ and 15.5\% (all underlying results are available from the authors on request). The actual Duncan index rises with age, modestly in 1970 and by around $14 \%$ percent in 2012.

${ }^{27}$ We have also examined the implications of selection on these skills for the gender wage gap. Holding wages and overall employment in an occupation fixed, we examine the effect on male and female average wages of eliminating differential gender selection on observable occupational attributes. This exercise highlights a somewhat surprising feature of skill-based occupational segregation: in many cases, it favors women in terms of compensation. Eliminating selection on physical strength or people/things orientation substantially increases the gender wage gap
} 


\section{Conclusions}

Research from a number of fields indicates that males and female differ, on average, in a number of sensory, motor and spatial aptitudes that are potentially important for occupational choice. We bring these findings to the puzzle of persistent gender based occupational segregation in the US labor market. Our results suggest that males and females select into occupations in ways predicted by this research. For example, males have been found to have a higher tolerance of noise and are found disproportionately in noisy occupations. We simulate that occupational segregation is higher than it would otherwise be as a result of this selection.

Conditional on our mapping of the research on sex differences in aptitudes into DOT occupational attributes, in both 1970 and 2012, absent this selection the Duncan index of occupational segregation would be, all else equal, 20-23 percent lower than its observed level.

We also compare the quantitative importance of these variables to a set of variables intended to capture competing hypotheses of the sources of gender segregation. While we find that some of these alternative hypotheses do account for gender segregation, they are generally less important quantitatively than our measures of sensory, motor and spatial skills. Gender differences in spatial skills in particular appear to have an important relative impact on gender segregation.

We should note that these comparisons are contingent on the ability of the DOT data to capture the different explanations of gender based occupational segregation, and any bias from important factors omitted from our regressions. One might argue that the inability of the DOT

in both years, while eliminating selection on sensory or motor skills increases the wage gap in 2012 (but decreases it in 1970). This suggests that women's skill/preference profile on these measures is relatively beneficial. In contrast, eliminating selection on cognitive skills (particularly math), spatial skills and measures of occupational risk lead to a lower gender wage gap in both years, but particularly in 2012. These results also underline that the significance of the segregation of males and females in employment for the gender gap in pay is dependent on the relative prices of these skills at a particular time and place. These results are available from the authors on request. 
variables to perfectly capture different aspects of occupations biases our results against finding an impact of a given explanation. The DOT variables were not developed with the specific aim of evaluating any of the explanations we consider, although they clearly capture some salient dimensions of each. We argue that the first message of the analysis is the relative importance of gender differences in sensory, motor and especially spatial aptitudes for occupational segregation, all skills that typically have not been highlighted in much of the research in this area.

The findings also highlight a lesson from the literature on these sex differences for research on the task content of jobs. The choice of specific DOT or O*NET skills to represent specific tasks may not be innocuous, particularly if differences across genders are to be compared or contrasted. ${ }^{28}$

In their recent study of gender occupational segregation Blau et al. (2013) observe that for significant desegregation in the future, "women would need to begin to make significant inroads into areas where they have not so far, especially predominantly male blue-collar jobs, and continue to build on their gains in STEM fields; and/or men would need to enter predominantly female occupations in much larger numbers than they have in the past” (p. 490). Our results point to some hypotheses of why these inroads are yet to be made.

\footnotetext{
${ }^{28}$ For example the DOT aptitudes Finger Dexterity (a fine motor skill) and Eye-Hand-Foot coordination (a gross motor skill) are used to represent routine and non routine manual skills respectively in the Autor et al. (2003) taxonomy of tasks. These skills are shown in tables 2-4 to have strong relationships with the log odds of male employment, particularly when used in isolation. Correspondingly, Autor and Price (2013) report persistent gender gaps between 1960 and 2010 in both routine and non routine manual skills employment using this taxonomy. In contrast Black and Spitz-Oener (2010) report large changes in the gender differences between 1979 and 1999 in routine and non routine manual tasks for West Germany using broader definitions of the associated aptitudes and activities.
} 


\section{References}

Abramov, Israel, Gordon, James, Feldman, Olga and Alla Chavarga, (2012a) "Sex \& Vision I: Spatio-temporal Resolution” Biology of Sex Differences, 3(1) 20

Abramov, Israel, Gordon, James, Feldman, Olga and Alla Chavarga, (2012b) "Sex and Vision II: Color Appearance of Monochromatic Lights” Biology of Sex Differences, 3(1) 21.

Akerlof, George A. and Rachel E. Kranton. (2000) “Economics and Identity.” Quarterly Journal of Economics. August, 105: 3, pp. 715-53.

Autor, David H., Frank Levy, and Richard J. Murnane. (2003) “The Skill Content of Recent Technological Change: An Empirical Exploration.” Quarterly Journal of Economics, 118(4) 1279-1333.

Autor, David H and Breden Pruice, (2013) “The Changing Task Composition of the US Labor Market: An Update of Autor, Levy and Murname (2003)”, mimeo MIT.

Auyeung Bonnie, Knickmeyer, Rebecca, Ashwin, Emma, Taylor, Kevin, Hackett, Gerald and Simon Baron-Cohen et al. (2011) "Effects of Fetal Testosterone on Visuospatial Ability”, Archives of Sexual Behavior, 41 (2012), 571-581.

Bacolod, Marigee and Bernardo S. Blum (2010). “Two Sides of the Same Soin: U.S. "Residual” Inequality and the Gender Gap.” Journal of Human Resources 45(1): 197-242.

Baker, Michael and Kirsten Cornelson, (2016), “Title IX and the Spatial Content of Female Employment-Out of the Lab and into the Labor Market” NBER Working Paper no. 22641.

Bielby, William T. and James N. Barron (1986). "Men and Women at Work: Sex Segregation and Statistical Discrimination.” American Journal of Sociology, 91(4) 759-799.

Black, Sandra and Alexandra Spitz-Oener, (2010.) "Explaining Women's Success: Technological Change and the Skill Content of Women's Work.” The Review of Economics and Statistics 92(1) 187-194.

Blau, Francine D. and Lawrence M. Kahn (2000), “Gender Differences in Pay”, Journal of Economic Perspectives, 14(4) 75-99.

Blau, Francine D., Brummund, Peter and Albert Yung-Hsu Liu (2013), “Trends in Occupational Segregation by Gender 1970-2009: Adjusting for the Impact of Changes in the Occupational Coding System”, Demography 50, 471-492

Blau Weiskoff, Francine, (1972) “'Women's Place’ in the Labor Market”, American Economic Review, 62(1/2) 161-166. 
Bonin, Holger, Thomas Dohman, Armin Falk, David Huffman and Uwe Sunde (2007). “Crosssectional Earnings Risk and Occupational Sorting: the Role of Risk Attitudes.” Labour Economics 14: 926-937.

Borghans, Lex, Ter Weel, Bas and Bruce A. Weinberg, (2014) "People Skills and the LaborMarket Outcomes 'of' Underrepresented Groups”, Industrial and Labor Relations Review 67(2) 287-334.

Brand, Gérard and Jean-Louis Millot (2001) “Sex Differences in Human Olfaction: Between Evidence and Enigma”, The Quarterly Journal of Experimental Psychology Section B: Comparative and Physiological Psychology, 54(3), 259-270

Brizendine, Louann, (2007) The Female Brain New York: Bantam.

Bureau of Labor Statistics (2015). "Highlights of Women’s Earnings in 2014, November.” Report 1058.

Burns, Nicholas R, and T Nettelbeck, (2005) "Inspection Time and Speed of Processing: Sex Differences on Perceptual Speed but not IT” Personality and Individual Differences 39 (2), 439-446.

Buser, Thomas, Muriel Niederle and Hessel Oosterbeek (2014). "Gender, Competitiveness and Career Choices.” Quarterly Journal of Economics 129(3): 1409-1447.

CANSIM, Statistics Canada, Ottawa, accessed December 3, 2015.

Case A. and C Paxson, (2008) "Stature and Status: Height, Ability, and Labor Market Outcomes” Journal of Political Economy 116(3) 499-532.

Cherney Isabelle D. and Daniel Voyer (2010) “Development of a Spatial Activity Questionnaire I: Items Identification” Sex Roles 62 89-99.

Cotton, Christopher, Frank McIntyre and Joseph Price (2013). “Gender Differences in Repeated Competition: Evidence from School Math Contests.” Journal of Economic Behavior and Organization 86: 52-66.

Croson, Rachel and Uri Gneezy (2009). “Gender Differences in Preferences.” Journal of Economic Literature 47(2): 448-474.

DeLeire, Thomas and Helen Levy (2004). "Worker Sorting and Risk of Death on the Job.” Journal of Labor Economics 22(4): 925-953.

Dickens, W.T, and J.R. Flynn (2001), "Heritability Estimates Versus Large Environmental Effects: The IQ Paradox Resolved,” Psychological Review, Vol. 108, No. 2, pp. 346-369.

Eckel, Catherine C., and Philip J., Grossman (2008) "Differences in the Economic Decisions of Men and Women: Experimental Evidence.” In: Plott, Charles, Smith, Vernon (Eds.), 
Handbook of Experimental Economics Results, vol. 1. Elsevier, New York.

Falter, C.M., Arroyo, M., and G.J Davis, (2006) "Testosterone: Activation or Organization of Spatial Cognition?”, Biological Psychology 73, 132-140.

Fine, Cordelia (2010) Delusions of Gender: How Our Minds, Society and Neurosexism Create a Difference. New York: W.W. Norton Company; 2010.

Garrett, John W (1971) "The Adult Human Hand: Some Anthropometric and Biomechanical Considerations” Human Factors, 13(2)117-131

Gilligan, Carol (2001). In a Different Voice: Psychological Theory and Women's Development. Cambridge, MA: Harvard University Press.

Gneezy, Uri, Niederle, Muriel, Rustichini, Aldo, 2003. "Performance in Competitive Environments: Gender Differences.” Quarterly Journal of Economics. 118, 1049-1074.

Goldin, Claudia (2013) “A Pollution Theory of Discrimination: Male and Female Differences in Occupations and Earnings", Harvard University.

Goldin, Claudia (2014), “A Grand Gender Convergence: Its Last Chapter”, American Economic Review, 104(4) 1091-1119.

Grazier, S. and P.J. Sloane (2008). “Accident Risk, Gender, Family Status and Occupational Choice in the UK.” Labour Economics 15(5): 938-957.

Guerra, R.S., Fonseca, I, Pichel, F, Restivo M.T. and T F Amaral (2014) "Hand length as an alternative measurement of height” European Journal of Clinical Nutrition 68, 229-233.

Gross, Edward (1968). "Plus Ça Change,„,? The Sexual Structure of Occupations Over Time.” Social Problems 16 (2): 198-208.

Hall, J.A.Y. and D Kimura (1995) "Sexual Orientation and Performance on Sexually Dimorphic Motor Tasks”, Archives of Sexual Behavior 24(4) 395-407.

Halpern, Diane F. (2012), Sex Differences in Cognitive Abilities: 4th Edition, New York, NY: Psychology Press.

Handa, Robert J. and Robert F. McGivern (2015) Steroid Hormones, Receptors, and Perceptual and Cognitive Sex Differences in the Visual System, Current Eye Research, 40:2, 110127

Hyde, Jane Shibley, (2014) “Gender Similarities and Differences” Annual Review of Psychology, 65(3) 373-398.

Leeth, John D. and John Ruser (2006). "Safety Segregation: the Importance of Gender, Race, and Ethnicity on Workplace Risk.” Journal of Economic Inequality 4(2): 123-152. 
Levanon, Asaf and David B. Grusky, (2016) "The Persistence of Extreme Gender Segregation in the Twenty-first Century” American Journal of Sociology, 122(2) 573-619.

Lippa, Richard A., Collaer, Marcia L. Michael Peters (2008) “Sex Differences in Mental Rotation and Line Angle Judgments Are Positively Associated with Gender Equality and Economic Development Across 53 Nations”, Archives of Sexual Behavior, 39, 990-997.

Longman, R.S., Saklofske, D.H. and T.S. Fung, (2007) "WAIS-III percentile scores by education and sex for U.S. and Canadian populations” Assessment 14(4) 426-32.

Lordan, Grace and Jorn-Steffen Pischke (2016) “Does Rosie Like Riveting? Male and Female Occupational Choices”, NBER Working Paper \#22495

Lundborg P., Nystedt P. and D-O Rooth (2014) "Height and Earnings: The Role of Cognitive and Noncognitive Skills” Journal of Human Resources, 49(1) 141-166

Maccoby, Eleanor G., and Carol N. Jacklin. 1974. The Psychology of Sex Differences. Stanford, Calif.: Stanford University Press.

Mercer, Michele E., Suzanne C. Drodge, Mary L. Courage and Russell J. Adams (2014), “A Pseudoisochromatic Test of Color Vision for Human Infants”, Vision research, 100, 7277.

McCarthy, Margaret N. and Gregory F. Ball, (2011) "Tempests and Tales: Challenges to the Study of Sex Differences in the Brain”, Biology of Sex Differences, 2(4)

McFadden, Daniel (1978). "Modelling the choice of residential location.” In Spatial Interaction Theory and Planning Models, ed. Anders Karlqvist, Lars Lundqvist, Folke Snickars and Jorgen W. Weibull, Amsterdam, Netherlands: North Holland, 75-96.

McFadden, Dennis, (1998) “Sex Differences in the Auditory System”, Developmental Neuropsychology, 14(2/3) 261-298.

McFadden, Dennis, (2002) “Masculinization Effects in the Auditory System”, Archives of Sexual Behavior, 31(1) 99-111.

McFadden, Dennis, (2008) "Masculinization of Mammalian Cochlea”, Hearing Research, 252, 37-48.

Miller, David I. and Diane F. Halpern, (2013), “Can Spatial Training Improve Long-term Outcomes for Gifted STEM Undergraduates?”, Learning and Individual Differences, 26 141-152.

Miller, David I. and Diane F. Halpern, (2014), “The New Science of Cognitive Sex Differences.” Trends in Cognitive Sciences 18(1), 37-45 
Murray IJ, Parry NR, McKeefry DJ, and A. Panorgias_(2012), "Sex-Related Differences in Peripheral Human Color Vision: a Color Matching Study” Journal of Vision 12(1)

Moore DS, Johnson SP. (2008) “Mental Rotation in Human Infants” Psychological Science 19:1063-66.

Nakao, Keiko, and Judith Treas. (1994) "Updating Occupational Prestige and Socioeconomic Scores: How the New Measures Measure Up.” In Marsden, Peter V. (ed.) Sociological Methodology 1994, Cambridge: Blackwell Publishers 1-72.

Newcombe, Nora S, (2010), “On Tending to our Scientific Knitting: Thinking about Gender in the Context of Evolution”. In J. Chrisler and D. McCreary (Eds.), Handbook of gender research in psychology, Springer, 259-274.

Nicholson KG, and D. Kimura (1996) "Sex Differences for Speech and Manual Skill” Perceptual and Motor Skills 82, 3-13.

Niederle, Muriel and Lise Vesterlund (2007). “Do Women Shy Away from Competition? Do Men Compete too Much?” Quarterly Journal of Economics 122(3): 1067-1101.

Office for National Statistics, (2015) “Annual Survey of Hours and Earnings, 2015 Provisional Results, November 18, 2015

Pan, Jessica (2015), “Gender Segregation in Occupations: The Role of Tipping and Social Interactions”, Journal of Labor Economics, 33(2), 365-408.

Persico, N., Postlewaite, A. and D Silverman, 2004) “The Effect of Adolescent Experience on Labor Market Outcomes: The Case of Height” Journal of Political Economy, 112(5) 1019-1053.

Peters, M., Servos, P., \& Day, R. (1990). “Marked Sex Differences on a Fine Motor Skill Task Disappear when Finger Size is used as a Covariate” Journal of Applied Psychology, 75(1), 87-90.

Peters, M., \& Campagnaro, P. (1996). “Do Women Really Excel over Men in Manual Dexterity?” Journal of Experimental Psychology: Human Perception and Performance, 22(5), 1107-1112.

Peters, Ryan M., Hackeman, Erik and Daniel Goldreich (2009) “Diminutive Digits Discern Delicate Details: Fingertip Size and the Sex Difference in Tactile Spatial Acuity”, The Journal of Neuroscience, 29(50),15756 -15761

Polachek, Solomon William, (1981) “Occupational Self-Selection: A Human Capital Approach to Sex Differences in Occupational Structure”, The Review of Economics and Statistics, 63(1) 60-69. 
Quinn PC, and LS. Liben (2008). “A Sex Difference in Mental Rotation in Young Infants.” Psychological Science 19: 1067-70

Roivainen, Eka (2011) “Gender Differences in Processing Speed: A Review of Recent Research.” Learning and Individual Differences 21: 145-149

Riach, Peter A. and Judith Rich (2002). "Field Experiments of Discrimination in the Market Place.” Economic Journal 112(483): F480-F518.

Riach, Peter A. and Judith Rich (2006). “An Experimental Investigation of Sexual Discrimination in Hiring in the English Labor Market.” B.E. Journal of Economic Analysis and Policy: Advances in Economic Analysis and Policy 6(2): 1-20.

Ruggles, Steven, Katie Genadek, Ronald Goeken, Josiah Grover, and Matthew Sobek. Integrated Public Use Microdata Series: Version 6.0 [dataset]. Minneapolis: University of Minnesota, 2015.

Sanders, Geoff (2013) "Sex Differences in Motor and Cognitive Abilities Predicted from Human Evolutionary History with Some Implications for Models of the Visual System”, The Journal of Sex Research, 50:3-4, 353-366.

Sanders, Geoff., and Kadam, A. (2001), "Prepubescent Children Show the Adult Relationship between Dermatoglyphic Asymmetry and Performance on Sexually Dimorphic Tasks”. Cortex, 37, 91-100.

Sanders, Geoff., and Perez, M. (2007). Sex differences in performance with the hand and arm in near and far space: A possible effect of tool use. Evolutionary Psychology, 5, 786-800.

Sanders, Geoff., and Walsh, T. (2007). Testing predictions from the hunter-gatherer hypothesis 1: Sex differences in the motor control of hand and arm. Evolutionary Psychology, 5, 653-665.

Sanders, Geoff, Kamila Sinclair, and Tom Walsh, (2007a) "Testing Predictions from the HunterGatherer Hypothesis - 1: Sex Differences in the Motor Control of hand and Arm”, Evolutionary Psychology, 5(3): 653-665.

Sanders, Geoff, Kamila Sinclair, and Tom Walsh, (2007b) “Testing Predictions from the HunterGatherer Hypothesis - 2: Sex Differences in the Visual Processing of Near and Far Space”, Evolutionary Psychology, 5(3): 666-679.

Stancy, Helen and Mark Turner, (2010), “Close Women, Distant Men: Line Bisection reveals Sex-Dimorphic Patterns of Visuomotor Performance in Near and Far Space”, British Journal of Psychology, 101(2), 293-309.

Suseelamma, D. (2014) "Study of Correlation between Stature and Length of Fingers" Scholars Journal of Applied Medical Sciences 2(2D):773-784 
U.S. Department of Commerce (2011) “Women in STEM: A Gender Gap to Innovation”, ESA Issue Brief \#04-11, August.

U.S. Department of Labor Employment and Training Administration (1991), The Revised Handbook for Analyzing Jobs, Washington D.C.

Velle, Weiert, (1987), “Sex Differences in Sensory Functions”, Perspectives in Biology and Medicine, 30(4), 490-522.

Ward, P., Farrow, D., Harris, K.R., Williams, A.M., Eccles, D.W. and, K.A. Ericsson, (2008), "Training Perceptual-Cognitive Skills: Can Sport Psychology Research Inform Military Decision Training?” Military Psychology 20, S71-S102.

Watson, N.V., and Kimura, D. (1991). "Non-Trivial Sex Differences in Throwing and Intercepting: Relation to Psychometrically-Defined Spatial Functions”. Personality and Individual Differences, 12, 375-385.

Weinberger, Catherine J. (1999). ’Mathematics Test Scores, Gender, Race, Ethnicity and the Science and Engineering Workforce.” Unpublished Manuscript, University of California, Santa Barbara.

Zhou, Liu, Ooi, Teng Leng and Zijiang J. He, (2016), “Intrinsic spatial knowledge about terrestrial ecology favors the tall for judging distance”, Science Advances 2(8) 


\section{Appendix}

Table A1 - DOT and O*NET measures of sensory, motor and spatial skills and aptitudes

\begin{tabular}{|c|c|c|c|c|}
\hline $\begin{array}{l}\text { DOT measure(s) } \\
\text { (type) }\end{array}$ & Scale & $\begin{array}{l}\text { Expected } \\
\text { coefficient on } \\
\text { "male" }\end{array}$ & Description** & Occupations with highest/lowest rating \\
\hline $\begin{array}{l}\text { Color } \\
\text { discrimination } \\
\text { (aptitude) }\end{array}$ & 1 to $5 *$ & - & $\begin{array}{l}\text { "The ability to match or discriminate between } \\
\text { colors in terms of hue, saturation, and brilliance. } \\
\text { Ability to identify a particular color combination } \\
\text { from memory and to perceive contrasting color } \\
\text { combinations." }\end{array}$ & $\begin{array}{l}\text { Misc. personal appearance workers/ } \\
\text { boilermakers }\end{array}$ \\
\hline $\begin{array}{l}\text { Color vision } \\
\text { (physical demand) }\end{array}$ & 0 to 3 & - & "Ability to identify and distinguish colors" & $\begin{array}{l}\text { Motion picture projectionists/ } \\
\text { mathematicians }\end{array}$ \\
\hline $\begin{array}{l}\text { Near visual acuity } \\
\text { (physical demand) }\end{array}$ & 0 to 3 & - & “Clarity of vision at 20 inches or less.” & $\begin{array}{c}\text { Tellers/ } \\
\text { dancers and choreographers }\end{array}$ \\
\hline $\begin{array}{l}\text { Far visual acuity } \\
\text { (physical demand) }\end{array}$ & 0 to 3 & + & "Clarity of vision at 20 feet or more" & $\begin{array}{l}\text { Bus drivers/ } \\
\text { lawyers }\end{array}$ \\
\hline $\begin{array}{l}\text { Hearing } \\
\text { (physical demand) }\end{array}$ & 0 to 3 & - & "Perceiving the nature of sounds by ear." & $\begin{array}{c}\text { Lawyers/ } \\
\text { dancers and choreographers }\end{array}$ \\
\hline $\begin{array}{l}\text { Noise } \\
\text { (environmental } \\
\text { condition) }\end{array}$ & 1 to 5 & + & $\begin{array}{l}\text { "The noise intensity level to which the worker is } \\
\text { exposed in the job environment" }\end{array}$ & $\begin{array}{l}\text { Misc. construction operators/ } \\
\text { chiropractors }\end{array}$ \\
\hline $\begin{array}{l}\text { Taste/smell } \\
\text { (physical demand) }\end{array}$ & 0 to 3 & - & $\begin{array}{l}\text { "Distinguishing, with a degree of accuracy, } \\
\text { differences or similarities in intensity or quality } \\
\text { of flavors or odors, or recognizing particular } \\
\text { flavors or odors, using tongue or nose.” }\end{array}$ & $\begin{array}{c}\text { Meter readers, utilities/ } \\
\text { plasterers and stucco masons }\end{array}$ \\
\hline $\begin{array}{l}\text { Feeling } \\
\text { (physical demand) }\end{array}$ & 0 to 3 & - & $\begin{array}{l}\text { "Perceiving attributes of objects, such as size, } \\
\text { shape, temperature, or texture, by touching with } \\
\text { skin, particularly that of fingertips." }\end{array}$ & $\begin{array}{l}\text { Chiropractors/ } \\
\text { actuaries }\end{array}$ \\
\hline
\end{tabular}




\begin{tabular}{|c|c|c|c|c|}
\hline $\begin{array}{l}\text { Finger dexterity } \\
\text { (aptitude) }\end{array}$ & 1 to $5^{*}$ & - & $\begin{array}{l}\text { "The ability to move the fingers and manipulate } \\
\text { small objects with the fingers rapidly or } \\
\text { accurately." }\end{array}$ & $\begin{array}{l}\text { Dentists/ } \\
\text { clergy }\end{array}$ \\
\hline $\begin{array}{l}\text { Fingering } \\
\text { (physical demand) }\end{array}$ & 0 to 3 & - & $\begin{array}{l}\text { "Picking, pinching, or otherwise working } \\
\text { primarily with fingers rather than with the whole } \\
\text { hand or arm as in handling." }\end{array}$ & $\begin{array}{c}\text { Tellers/ } \\
\text { dancers and choreographers }\end{array}$ \\
\hline $\begin{array}{l}\text { Motor } \\
\text { coordination } \\
\text { (aptitude) }\end{array}$ & 1 to $5^{*}$ & - & $\begin{array}{l}\text { "The ability to coordinate eyes and hands or } \\
\text { fingers rapidly and accurately in making precise } \\
\text { movements with speed. Ability to make a } \\
\text { movement response accurately and swiftly" }\end{array}$ & $\begin{array}{l}\text { Dancers and choreographers/ } \\
\text { meter readers, utilities }\end{array}$ \\
\hline $\begin{array}{l}\text { Eye-hand-foot } \\
\text { coordination } \\
\text { (aptitude) }\end{array}$ & 1 to $5^{*}$ & + & $\begin{array}{l}\text { "The ability to move the hand and foot } \\
\text { coordinately with each other in accordance with } \\
\text { visual stimuli." }\end{array}$ & $\begin{array}{l}\text { Dancers and choreographers/ } \\
\text { boilermakers }\end{array}$ \\
\hline $\begin{array}{l}\text { Clerical perception } \\
\text { (aptitude) }\end{array}$ & 1 to $5^{*}$ & - & $\begin{array}{l}\text { "The ability to perceive pertinent detail in verbal } \\
\text { or tabular material. Ability to observe } \\
\text { differences in copy, to proofread words and } \\
\text { numbers, and to avoid perceptual errors in } \\
\text { arithmetic computation. A measure of speed of } \\
\text { perception is required in many industrial jobs } \\
\text { even when the job does not have verbal or } \\
\text { numerical content." }\end{array}$ & $\begin{array}{c}\text { Computer programmers/ } \\
\text { pressers, textile, garment and related materials }\end{array}$ \\
\hline $\begin{array}{l}\text { Manual dexterity } \\
\text { (aptitude) }\end{array}$ & 1 to $5^{*}$ & $?$ & $\begin{array}{l}\text { "The ability to move the hands easily and } \\
\text { skillfully. Ability to work with the hands in } \\
\text { placing and turning motions...manual dexterity } \\
\text { involves working with the arms and } \\
\text { hands...Finger movements may or may not } \\
\text { accompany the exercise of manual dexterity.” }\end{array}$ & $\begin{array}{l}\text { Veterinarians/ } \\
\text { meter readers, utilities }\end{array}$ \\
\hline $\begin{array}{l}\text { Handling } \\
\text { (physical demand) }\end{array}$ & 0 to 3 & - & $\begin{array}{l}\text { "Seizing, holding, grasping, turning, or } \\
\text { otherwise working with hand or hands." }\end{array}$ & $\begin{array}{l}\text { Optometrists/ } \\
\text { dancers and choreographers }\end{array}$ \\
\hline
\end{tabular}




\begin{tabular}{|c|c|c|c|c|}
\hline $\begin{array}{l}\text { Spatial } \\
\text { (aptitude) }\end{array}$ & 1 to $5^{*}$ & + & $\begin{array}{l}\text { "The ability to think visually of geometric forms } \\
\text { and to comprehend the two-dimensional } \\
\text { representation of three-dimensional objects. The } \\
\text { ability to recognize the relationships resulting } \\
\text { from the movement of objects in space." }\end{array}$ & $\begin{array}{l}\text { Optometrists/ } \\
\text { insurance sales agents }\end{array}$ \\
\hline $\begin{array}{l}\text { Depth perception } \\
\text { (physical demand) }\end{array}$ & 0 to 3 & + & $\begin{array}{l}\text { “Three-dimensional vision. Ability to judge } \\
\text { distances and spatial relationships so as to see } \\
\text { objects where and as they actually are.” }\end{array}$ & $\begin{array}{l}\text { Bus drivers/ } \\
\text { sociologists }\end{array}$ \\
\hline \multicolumn{5}{|c|}{ Other Aptitudes and Attributes } \\
\hline GED language & 1 to 5 & & $\begin{array}{l}\text { “...though language courses follow a...pattern of } \\
\text { progression in primary and secondary school, } \\
\text { particularly in learning and applying the } \\
\text { principles of grammar, this pattern changes at the } \\
\text { college level. The diversity of language courses } \\
\text { offered at the college level precludes the } \\
\text { establishment of distinct levels of language } \\
\text { progression for these four years. Consequently, } \\
\text { language development is limited to five defined } \\
\text { levels of GED.” }\end{array}$ & $\begin{array}{l}\text { Clergy/ } \\
\text { parking lot attendants }\end{array}$ \\
\hline GED math & 1 to 6 & & $\begin{array}{l}\text { "The description of the various levels of } \\
\text { language and mathematical development are } \\
\text { based on the curricula taught in schools } \\
\text { throughout the United States. An analysis of } \\
\text { mathematics courses in school curricula reveals } \\
\text { distinct levels of progression in the primary and } \\
\text { secondary grades and in college. These levels of } \\
\text { progression facilitated the selection and } \\
\text { assignment of six levels of GED for the } \\
\text { mathematical development scale.” }\end{array}$ & $\begin{array}{l}\text { Mathematicians/ } \\
\text { parking lot attendants }\end{array}$ \\
\hline $\begin{array}{l}\text { Temperament - } \\
\text { dealing with } \\
\text { people }\end{array}$ & 0 to 1 & & $\begin{array}{l}\text { “...interpersonal relationships in job situations } \\
\text { beyond receiving work instructions.” }\end{array}$ & $\begin{array}{l}\text { Recreational therapists/ } \\
\text { dancers and choreographers }\end{array}$ \\
\hline
\end{tabular}




\begin{tabular}{|c|c|c|c|}
\hline Interests - things & 0 to 1 & $\begin{array}{l}\text { “Things Functions can be divided into } \\
\text { relationships based upon the worker's } \\
\text { involvement with either machine and equipment } \\
\text { (machine related) or with tools and work aids } \\
\text { (non-machine related)...Things Functions also } \\
\text { represent levels of complexity based on the } \\
\text { worker's decisions or judgements.” }\end{array}$ & $\begin{array}{l}\text { Parking lot attendants/ } \\
\text { audiologists }\end{array}$ \\
\hline Physical strength & 1 to 5 & $\begin{array}{l}\text { "This factor is expressed by one of five terms: } \\
\text { Sedentary, Light, Medium, Heavy and Very } \\
\text { Heavy" }\end{array}$ & Therapists, all other / statisticians \\
\hline $\begin{array}{l}\text { Level of } \\
\text { competition }\end{array}$ & 1 to 5 & $\begin{array}{l}\text { To what extent does this job require the worker } \\
\text { to compete or to be aware of competitive } \\
\text { pressures? }\end{array}$ & Photographers/Crossing Guards \\
\hline Time pressure & 1 to 5 & $\begin{array}{l}\text { How often does this job require the worker to } \\
\text { meet strict deadlines? }\end{array}$ & $\begin{array}{c}\text { Plating and Coating Machine Setters, Operators, } \\
\text { and Tenders, Metal and Plastic/Bartenders }\end{array}$ \\
\hline $\begin{array}{l}\text { Structured vs. } \\
\text { unstructured work }\end{array}$ & 1 to 5 & $\begin{array}{l}\text { To what extent is this job structured for the } \\
\text { worker, rather than allowing the worker to } \\
\text { determine tasks, priorities, and goals? (Note: } \\
\text { higher values imply more freedom for the } \\
\text { worker) }\end{array}$ & Chiropractors/Telephone operators \\
\hline $\begin{array}{l}\text { Freedom to make } \\
\text { decisions }\end{array}$ & 1 to 5 & $\begin{array}{l}\text { How much decision making freedom, without } \\
\text { supervision, does the job offer? }\end{array}$ & $\begin{array}{c}\text { Gaming managers/Graders and Sorters, } \\
\text { Agricultural Products }\end{array}$ \\
\hline
\end{tabular}

* Reverse coded in original data; re-labelled to be in increasing order of skill. ** Source-US Department of Labor (1991). 


\section{Data Methods}

Converting Census data into 2000 Census occupation codes

In our analysis, we use the $1 \%$ Census samples provided by the IPUMS website, as well as the 2012 three-year ACS. We restrict the sample to 18-64 year olds who are employed in the civilian labor force, with non-allocated occupation codes.

To ensure comparability with previous work on occupational segregation, we use the 2000 Census occupation codes throughout our analysis. To convert the 1970 Census data to the year 2000 codes, we follow the procedure outlined in Blau et al. (2013). We start by converting the 1970 data to 1980 codes using the gender-specific crosswalk provided by the Census Bureau (available on IPUMS at https://usa.ipums.org/usa/resources/chapter4/occ_70-80.pdf). There were minimal changes between the 1980 and 1990 coding systems. For 1980 occupations that were combined into a single 1990 occupation (six pairs), we simply add the number of men/women in each 1980 occupation to arrive at the 1990 total. For the 1980 occupations that were split in the 1990 coding system, we redistribute the number of 1980 incumbents into the 1990 codes based on the distribution of employment in 1990. Finally, we use the crosswalk developed by Blau et al. (2013) to convert the data into the 2000 Census codes.

The 2012 ACS occupation codes are similar to those used in the 2000 Census. For the occupations that did experience changes from the 2000 Census to the ACS, we follow a procedure that is similar to that used in converting the 1980 data to 1990 codes.

Converting DOT data to 2000 Census occupation codes

The DOT77 data was obtained from a 1971 CPS file, augmented with DOT ratings, which is available from the ICPSR website. This file contains both the DOT occupational coding and the 1970 census occupational coding. Because each 1970 occupation contains several DOT 
occupations, we calculate the DOT rating for each 1970 occupation using an employmentweighted mean. We use procedures similar to that described in the Census data to convert the ratings to the 2000 Census occupation coding, taking employment-weighted means at each step. Note that the crosswalks used in this process are not gender specific; each 2000 Census occupation is given a single DOT rating, not a separate rating for men and women.

The DOT91 data was also obtained from the ICPSR website. DOT91 ratings are only available for the 1991 DOT occupational coding. Most occupations had the same coding in 1977 and 1991. A list of exceptions was available in the ICPSR documentation, which was used to convert the remaining occupations (do-files available upon request.) Once the data was consistent with the 1977 coding system, the 1991 data was merged onto the 1971 CPS file, and was then converted to the 2000 Census codes in the same was as the 1977 data.

There are 505 occupations in the 2000 occupation coding system. Of these, 478 had nonzero employment for both men and women, in both 1970 and 2012. Another 2 occupations could not be matched to the DOT data, resulting in a sample of 476 occupations that could be matched to the DOT data.

Converting $O * N E T$ and fatalities data to 2000 Census occupation codes

The O*NET and Census of Fatal Injuries data are provided at the SOC occupation level. To convert these to Census Occupational Coding, we use the crosswalk provided by IPUMS. 494 Census occupations could be linked to the O*NET data; of these, 468 overlap with the DOT data and have non-zero employment for both men and women in both years. These 468 occupations represent our final sample. 
Table A2- Sensitivity Analysis- Changes in the specification occupational skills and attributes

\begin{tabular}{|c|c|}
\hline Alternative specification & $\begin{array}{l}\text { Results (Based on the full specification with all } \\
\text { variables.) }\end{array}$ \\
\hline $\begin{array}{l}\text { Controlling for the ratio of wages and hours } \\
\text { worked }\end{array}$ & $\begin{array}{l}\text { The results are similar. Adding these to the } \\
\text { controls, the predicted Duncan indices (negating } \\
\text { selection on all attributes) are } 0.410 \text { and } 0.292 \text {, } \\
\text { compared to } 0.420 \text { and } 0.299 \text { in our main analysis. }\end{array}$ \\
\hline $\begin{array}{l}\text { Using only one of color discrimination or color } \\
\text { vision }\end{array}$ & $\begin{array}{l}\text { The results are similar if we drop either of these } \\
\text { variables. The predicted Duncan index ranges from } \\
0.418-0.424 \text { in } 1970 \text { and from } 0.297-0.299 \text { in } 2012 \text {, } \\
\text { depending on the combination used. }\end{array}$ \\
\hline Using only one of fingering or finger dexterity & $\begin{array}{l}\text { The results are similar if we drop either of these } \\
\text { variables. The predicted Duncan index ranges from } \\
0.419-0.422 \text { in } 1970 \text { and from } 0.299-0.304 \text { in } 2012 \text {, } \\
\text { depending on the combination used }\end{array}$ \\
\hline $\begin{array}{l}\text { Using only one of finger dexterity or motor } \\
\text { control }\end{array}$ & $\begin{array}{l}\text { The results are similar if we drop either of these } \\
\text { variables. The predicted Duncan index ranges from } \\
0.418-0.422 \text { in } 1970 \text { and from } 0.299-0.304 \text { in } 2012 \text {, } \\
\text { depending on the combination used. }\end{array}$ \\
\hline $\begin{array}{l}\text { Using only one of manual dexterity or motor } \\
\text { control. }\end{array}$ & $\begin{array}{l}\text { The results are similar if we drop either of these } \\
\text { variables. The predicted Duncan index ranges from } \\
0.418-0.422 \text { in } 1970 \text { and from } 0.298-0.299 \text { in } 2012 \text {, } \\
\text { depending on the combination used. }\end{array}$ \\
\hline $\begin{array}{l}\text { Controlling for alternative measures of the } \\
\text { social skill of employment-DOT interests } \\
\text { "activities involving contact with people", and } \\
\text { O*NET work context "contact with others" }\end{array}$ & $\begin{array}{l}\text { Using the "interests - activities involving contact } \\
\text { with people" measure results in a Duncan index of } \\
0.420 \text { in } 1970 \text { and } 0.300 \text { in } 2012 \text {. Using the } 0^{*} \text { NET } \\
\text { work context "contact with others" results in a } \\
\text { Duncan index of } 0.420 \text { in } 1970 \text { and } 0.300 \text { in } 2012 .\end{array}$ \\
\hline Alternative specification & $\begin{array}{l}\text { Results (Based on the full specification with all } \\
\text { variables.) }\end{array}$ \\
\hline $\begin{array}{l}\text { Switching to } 1991 \text { DOT definitions for both } \\
\text { years }\end{array}$ & $\begin{array}{l}\text { The only variable that changes significance is } \\
\text { tasting-smelling, which would not have been } \\
\text { significant in } 1970 \text { if the } 1991 \text { definitions had been } \\
\text { used. If } 1991 \text { definitions are used, the predicted } \\
\text { Duncan index (negating selection on all } \\
\text { occupational attributes) becomes } 0.414 \text { in } 1970 \text {, as } \\
\text { opposed to } 0.420 \text { in our main analysis. }\end{array}$ \\
\hline $\begin{array}{l}\text { Switching to } 1977 \text { DOT definitions for both } \\
\text { years }\end{array}$ & $\begin{array}{l}\text { The coefficient on clerical perception becomes } \\
\text { larger and significant at the } 5 \% \text { level in } 2012 \text { if the } \\
1977 \text { definitions are used; the coefficient on eye- } \\
\text { hand-foot coordination becomes smaller and } \\
\text { insignificant. All other coefficients remain of similar } \\
\text { magnitudes. If } 1977 \text { definitions are used, the } \\
\text { predicted Duncan index (negating selection on all } \\
\text { occupational attributes) becomes } 0.295 \text { in } 2012 \text {, as } \\
\text { opposed to } 0.299 \text { in our main analysis. }\end{array}$ \\
\hline
\end{tabular}


Table 1: Gender based occupational segregation in the US labor market

\begin{tabular}{|c|c|c|c|c|c|}
\hline & 1970 & 1980 & 1990 & 2000 & 2012 \\
\hline Duncan Index & 0.644 & 0.586 & 0.540 & 0.519 & 0.506 \\
\hline \multirow[t]{5}{*}{ Top 5 Occupations } & $\begin{array}{c}\text { Secretaries } \\
\text { and } \\
\text { administrative } \\
\text { assistants }\end{array}$ & $\begin{array}{c}\text { Secretaries } \\
\text { and } \\
\text { administrative } \\
\text { assistants }\end{array}$ & $\begin{array}{c}\text { Secretaries } \\
\text { and } \\
\text { administrative } \\
\text { assistants }\end{array}$ & $\begin{array}{c}\text { Secretaries } \\
\text { and } \\
\text { administrative } \\
\text { assistants }\end{array}$ & $\begin{array}{c}\text { Secretaries } \\
\text { and } \\
\text { administrative } \\
\text { assistants }\end{array}$ \\
\hline & $\begin{array}{l}\text { Driver/sales } \\
\text { workers and } \\
\text { truck drivers }\end{array}$ & $\begin{array}{l}\text { Driver/sales } \\
\text { workers and } \\
\text { truck drivers }\end{array}$ & $\begin{array}{l}\text { Driver/sales } \\
\text { workers and } \\
\text { truck drivers }\end{array}$ & $\begin{array}{l}\text { Driver/sales } \\
\text { workers and } \\
\text { truck drivers }\end{array}$ & $\begin{array}{l}\text { Registered } \\
\text { nurses }\end{array}$ \\
\hline & $\begin{array}{l}\text { Elementary } \\
\text { and middle } \\
\text { school } \\
\text { teachers }\end{array}$ & $\begin{array}{c}\text { Bookkeeping, } \\
\text { accounting } \\
\text { and auditing } \\
\text { clerks }\end{array}$ & $\begin{array}{l}\text { Elementary } \\
\text { and middle } \\
\text { school } \\
\text { teachers }\end{array}$ & $\begin{array}{l}\text { Registered } \\
\text { nurses }\end{array}$ & $\begin{array}{l}\text { Driver/sales } \\
\text { workers and } \\
\text { truck drivers }\end{array}$ \\
\hline & $\begin{array}{l}\text { Bookkeeping, } \\
\text { accounting } \\
\text { and auditing } \\
\text { clerks }\end{array}$ & $\begin{array}{l}\text { Elementary } \\
\text { and middle } \\
\text { school } \\
\text { teachers }\end{array}$ & $\begin{array}{l}\text { Registered } \\
\text { nurses }\end{array}$ & $\begin{array}{l}\text { Elementary } \\
\text { and middle } \\
\text { school } \\
\text { teachers }\end{array}$ & $\begin{array}{l}\text { Elementary } \\
\text { and middle } \\
\text { school } \\
\text { teachers }\end{array}$ \\
\hline & $\begin{array}{l}\text { Maids and } \\
\text { housekeeping } \\
\text { cleaners }\end{array}$ & $\begin{array}{l}\text { Registered } \\
\text { nurses }\end{array}$ & $\begin{array}{c}\text { Bookkeeping, } \\
\text { accounting } \\
\text { and auditing } \\
\text { clerks } \\
\end{array}$ & $\begin{array}{c}\text { Bookkeeping, } \\
\text { accounting } \\
\text { and auditing } \\
\text { clerks } \\
\end{array}$ & $\begin{array}{l}\text { Nursing, } \\
\text { psychiatric } \\
\text { and home } \\
\text { health aids }\end{array}$ \\
\hline $\begin{array}{l}\text { \% of Duncan Accounted } \\
\text { by top } 5 \text { Occupations }\end{array}$ & 20.7 & 21.3 & 21.3 & 17.9 & 17.4 \\
\hline $\begin{array}{l}\% \text { of Duncan Accounted } \\
\text { by STEM Occupations }\end{array}$ & 3.9 & 3.9 & 4.6 & 5.2 & 5.1 \\
\hline $\begin{array}{l}\text { Total Number of } \\
\text { Occupations }\end{array}$ & 505 & 505 & 505 & 505 & 505 \\
\hline $\begin{array}{l}\text { Number of Occupations } \\
\text { that account for } 50 \% \text { of } \\
\text { the Duncan }\end{array}$ & 25 & 26 & 28 & 31 & 31 \\
\hline $\begin{array}{l}\text { Number of Occupations } \\
\text { that account for } 90 \% \text { of } \\
\text { the Duncan }\end{array}$ & 166 & 172 & 177 & 176 & 172 \\
\hline
\end{tabular}

Notes: Authors’ calculations from 1970-2000 censuses and 2012 American Community Survey. 
Table 2: The relationship between the log odds ratio of male to female employment and measures of physical strength, language and math, people and things, occupational prestige, mortality risk and competitiveness, and time pressure, work structure and decision structure; univariate regressions

\begin{tabular}{|c|c|c|c|c|c|}
\hline & \multirow[b]{2}{*}{ Sign } & \multicolumn{2}{|c|}{1970} & \multicolumn{2}{|c|}{2012} \\
\hline & & Coefficient & $\mathrm{R}^{2}$ & Coefficient & $\mathrm{R}^{2}$ \\
\hline Physical strength & + & $\begin{array}{c}0.728 * * * \\
(0.084)\end{array}$ & 0.137 & $\begin{array}{c}0.996 * * * \\
(0.067)\end{array}$ & 0.319 \\
\hline GED - language & - & $\begin{array}{c}-0.091 \\
(0.091)\end{array}$ & 0.002 & $\begin{array}{l}-0.505^{* * *} \\
(0.078)\end{array}$ & 0.082 \\
\hline GED - math & + & $\begin{array}{c}0.226^{* *} \\
(0.090)\end{array}$ & 0.013 & $\begin{array}{c}-0.171^{* *} \\
(0.081)\end{array}$ & 0.009 \\
\hline Temperament - people & - & $\begin{array}{c}-0.714^{* * *} \\
(0.084)\end{array}$ & 0.132 & $\begin{array}{c}-0.946 * * * \\
(0.069)\end{array}$ & 0.287 \\
\hline Interest - things & + & $\begin{array}{c}0.747 * * * \\
(0.084)\end{array}$ & 0.145 & $\begin{array}{c}0.863 * * * \\
(0.071)\end{array}$ & 0.239 \\
\hline Occupational prestige & + & $\begin{array}{c}0.127 \\
(0.091)\end{array}$ & 0.004 & $\begin{array}{l}-0.238^{* * *} \\
(0.081)\end{array}$ & 0.018 \\
\hline Mortality risk & + & $\begin{array}{c}0.560^{* * *} \\
(0.087)\end{array}$ & 0.081 & $\begin{array}{c}0.602 * * * \\
(0.079)\end{array}$ & 0.116 \\
\hline Competition & + & $\begin{array}{c}0.457 * * * \\
(0.089)\end{array}$ & 0.054 & $\begin{array}{c}0.321^{* * *} \\
(0.080)\end{array}$ & 0.033 \\
\hline Time pressure & + & $\begin{array}{c}0.253 * * * \\
(0.090)\end{array}$ & 0.017 & $\begin{array}{c}0.228 * * * \\
(0.081)\end{array}$ & 0.017 \\
\hline $\begin{array}{l}\text { Structured/unstructured } \\
\text { work }\end{array}$ & + & $\begin{array}{c}0.044 \\
(0.091)\end{array}$ & 0.001 & $\begin{array}{c}-0.240 * * * \\
(0.081)\end{array}$ & 0.019 \\
\hline Freedom to make decisions & + & $\begin{array}{l}0.213^{* *} \\
(0.091)\end{array}$ & 0.012 & $\begin{array}{c}0.064 \\
(0.082)\end{array}$ & 0.001 \\
\hline
\end{tabular}

Notes: Authors' calculations from 1970 census and 2012 American Community Survey. Each estimate is from a separate regression of the log odds ratio of male to female employment at the occupational level on the indicated skill or aptitude. **, ** and $*$ indicate statistical significance at the 10,5 , and 1 percent levels respectively. 
Table 3: The relationship between the log odds ratio of male to female employment and measures of sensory, motor and spatial skills; univariate regressions

\begin{tabular}{|c|c|c|c|c|c|c|}
\hline & & \multicolumn{3}{|c|}{1970} & \multicolumn{2}{|c|}{2012} \\
\hline & & Sign & Coefficient & $\mathrm{R}^{2}$ & Coefficient & $\mathrm{R}^{2}$ \\
\hline \multirow[t]{8}{*}{ Sensory } & Color discrimination & - & $\begin{array}{l}0.157^{*} \\
(0.091)\end{array}$ & 0.007 & $\begin{array}{c}0.180^{* *} \\
(0.081)\end{array}$ & 0.010 \\
\hline & Color vision & - & $\begin{array}{c}0.450 * * * \\
(0.089)\end{array}$ & 0.052 & $\begin{array}{c}0.349 * * * \\
(0.080)\end{array}$ & 0.040 \\
\hline & Near acuity & - & $\begin{array}{l}-0.173^{*} \\
(0.091)\end{array}$ & 0.008 & $\begin{array}{c}-0.230 * * * \\
(0.082)\end{array}$ & 0.017 \\
\hline & Far acuity & + & $\begin{array}{c}0.594 * * * \\
(0.087)\end{array}$ & 0.091 & $\begin{array}{c}0.471^{* * *} \\
(0.078)\end{array}$ & 0.071 \\
\hline & Hearing & - & $\begin{array}{c}-0.542^{* * *} \\
(0.088)\end{array}$ & 0.077 & $\begin{array}{c}-0.800^{* * *} \\
(0.073)\end{array}$ & 0.205 \\
\hline & Noise & + & $\begin{array}{c}0.951^{* * *} \\
(0.080)\end{array}$ & 0.234 & $\begin{array}{c}1.170^{* * *} \\
(0.061)\end{array}$ & 0.440 \\
\hline & Tasting-smelling & - & $\begin{array}{c}-0.070 \\
(0.091)\end{array}$ & 0.001 & $\begin{array}{l}-0.037 \\
(0.081)\end{array}$ & 0.000 \\
\hline & Feeling & - & $\begin{array}{l}-0.154^{*} \\
(0.091)\end{array}$ & 0.006 & $\begin{array}{c}-0.132 \\
(0.081)\end{array}$ & 0.006 \\
\hline \multirow[t]{7}{*}{ Motor } & Fingering & - & $\begin{array}{c}-0.404 * * * \\
(0.090)\end{array}$ & 0.042 & $\begin{array}{c}-0.244 * * * \\
(0.081)\end{array}$ & 0.019 \\
\hline & Finger Dexterity & - & $\begin{array}{c}-0.148 \\
(0.091)\end{array}$ & 0.006 & $\begin{array}{c}-0.064 \\
(0.081)\end{array}$ & 0.001 \\
\hline & Handling & - & $\begin{array}{l}-0.020 \\
(0.091)\end{array}$ & 0.000 & $\begin{array}{c}0.277 * * * \\
(0.081)\end{array}$ & 0.025 \\
\hline & Manual dexterity & ? & $\begin{array}{c}0.452^{* * * *} \\
(0.089)\end{array}$ & 0.053 & $\begin{array}{c}0.672 * * * \\
(0.076)\end{array}$ & 0.145 \\
\hline & Motor Co-ordination & - & $\begin{array}{l}0.153^{*} \\
(0.091)\end{array}$ & 0.006 & $\begin{array}{c}0.336^{* * *} \\
(0.080)\end{array}$ & 0.036 \\
\hline & Eye-Hand-Foot & + & $\begin{array}{c}0.659 * * * \\
(0.086)\end{array}$ & 0.113 & $\begin{array}{c}0.736^{* * *} \\
(0.074)\end{array}$ & 0.174 \\
\hline & Clerical Perception & - & $\begin{array}{c}-0.543^{* * *} \\
(0.088)\end{array}$ & 0.076 & $\begin{array}{c}-0.855^{* * *} \\
(0.072)\end{array}$ & 0.235 \\
\hline \multirow[t]{2}{*}{ Spatial } & Spatial skills & + & $\begin{array}{c}0.908^{* * *} \\
(0.081)\end{array}$ & 0.214 & $\begin{array}{c}0.685 * * * \\
(0.075)\end{array}$ & 0.150 \\
\hline & Depth perception & + & $\begin{array}{c}1.052^{* * *} \\
(0.077)\end{array}$ & 0.286 & $\begin{array}{c}1.138 * * * \\
(0.062)\end{array}$ & 0.416 \\
\hline
\end{tabular}

Notes: Authors' calculations from 1970 census and 2012 American Community Survey. Each estimate is from a separate regression of the log odds ratio of male to female employment at the occupational level on the DOT measure of the indicated skill or aptitude. ${ }^{* * *}, * *$ and $*$ indicate statistical significance at the 10,5 , and 1 percent levels respectively. 
Table 4: The relationship between the log odds ratio of male to female employment and occupational skills, aptitudes and attributes; multivariate regressions

\begin{tabular}{|c|c|c|c|c|c|c|}
\hline & & \multicolumn{3}{|c|}{1970} & \multicolumn{2}{|c|}{2012} \\
\hline & & Sign & Coefficient & Partial $\mathrm{R}^{2}$ & Coefficient & Partial $\mathrm{R}^{2}$ \\
\hline \multirow[t]{8}{*}{ Sensory } & Color discrimination & - & $\begin{array}{l}-0.084 \\
(0.095)\end{array}$ & 0.002 & $\begin{array}{c}-0.298^{* * *} \\
(0.102)\end{array}$ & 0.019 \\
\hline & Color vision & - & $\begin{array}{c}-0.016 \\
(0.112)\end{array}$ & 0.000 & $\begin{array}{c}0.015 \\
(0.103)\end{array}$ & 0.000 \\
\hline & Near Acuity & - & $\begin{array}{c}0.016 \\
(0.088)\end{array}$ & 0.000 & $\begin{array}{l}-0.075 \\
(0.070)\end{array}$ & 0.003 \\
\hline & Far Acuity & + & $\begin{array}{c}0.290 * * * \\
(0.101)\end{array}$ & 0.019 & $\begin{array}{l}0.140^{*} \\
(0.080)\end{array}$ & 0.007 \\
\hline & Hearing & - & $\begin{array}{c}0.091 \\
(0.138)\end{array}$ & 0.001 & $\begin{array}{c}-0.003 \\
(0.110)\end{array}$ & 0.000 \\
\hline & Noise & + & $\begin{array}{c}0.316^{* * *} \\
(0.103)\end{array}$ & 0.021 & $\begin{array}{c}0.367 * * * \\
(0.081)\end{array}$ & 0.045 \\
\hline & Tasting-smelling & - & $\begin{array}{c}-0.135 * * \\
(0.064)\end{array}$ & 0.010 & $\begin{array}{c}-0.004 \\
(0.050)\end{array}$ & 0.000 \\
\hline & Feeling & - & $\begin{array}{c}-0.306^{* * *} \\
(0.081)\end{array}$ & 0.031 & $\begin{array}{c}-0.319^{* * *} \\
(0.066)\end{array}$ & 0.051 \\
\hline \multirow[t]{7}{*}{ Motor } & Fingering & - & $\begin{array}{c}0.013 \\
(0.099)\end{array}$ & 0.000 & $\begin{array}{c}0.109 \\
(0.080)\end{array}$ & 0.004 \\
\hline & Finger Dexterity & - & $\begin{array}{c}-0.316^{* *} \\
(0.128)\end{array}$ & 0.014 & $\begin{array}{l}-0.184^{*} \\
(0.101)\end{array}$ & 0.008 \\
\hline & Handling & - & $\begin{array}{c}-0.183^{* *} \\
(0.090)\end{array}$ & 0.009 & $\begin{array}{c}-0.092 \\
(0.070)\end{array}$ & 0.004 \\
\hline & Manual dexterity & $?$ & $\begin{array}{c}0.033 \\
(0.123)\end{array}$ & 0.000 & $\begin{array}{c}0.185 \\
(0.126)\end{array}$ & 0.005 \\
\hline & Motor Co-ordination & - & $\begin{array}{c}0.024 \\
(0.108)\end{array}$ & 0.000 & $\begin{array}{c}-0.078 \\
(0.096)\end{array}$ & 0.002 \\
\hline & Eye-Hand-Foot & + & $\begin{array}{c}-0.221^{* *} \\
(0.088)\end{array}$ & 0.014 & $\begin{array}{l}-0.144^{*} \\
(0.077)\end{array}$ & 0.008 \\
\hline & Clerical Perception & - & $\begin{array}{l}-0.196^{*} \\
(0.114)\end{array}$ & 0.007 & $\begin{array}{l}-0.141 \\
(0.107)\end{array}$ & 0.004 \\
\hline \multirow[t]{2}{*}{ Spatial } & Spatial skills & + & $\begin{array}{c}0.586 * * * \\
(0.107)\end{array}$ & 0.065 & $\begin{array}{c}0.296 * * * \\
(0.100)\end{array}$ & 0.020 \\
\hline & Depth perception & + & $\begin{array}{c}0.306^{* *} \\
(0.123)\end{array}$ & 0.014 & $\begin{array}{c}0.413 * * * \\
(0.099)\end{array}$ & 0.039 \\
\hline \multirow[t]{3}{*}{$\begin{array}{l}\text { Other } \\
\text { Attributes }\end{array}$} & Physical strength & + & $\begin{array}{c}0.466^{* * *} \\
(0.115)\end{array}$ & 0.036 & $\begin{array}{c}0.481^{* * *} \\
(0.108)\end{array}$ & 0.043 \\
\hline & GED - language & - & $\begin{array}{l}-0.085 \\
(0.178)\end{array}$ & 0.001 & $\begin{array}{c}-0.243 \\
(0.174)\end{array}$ & 0.004 \\
\hline & GED - math & + & $\begin{array}{c}0.484^{* * * *} \\
(0.148)\end{array}$ & 0.024 & $\begin{array}{c}0.552^{* * *} \\
(0.137)\end{array}$ & 0.036 \\
\hline
\end{tabular}




\begin{tabular}{|c|c|c|c|c|c|c|}
\hline & Temperament - people & - & $\begin{array}{l}-0.057 \\
(0.143)\end{array}$ & 0.000 & $\begin{array}{l}-0.114 \\
(0.112)\end{array}$ & 0.002 \\
\hline & Interest - things & + & $\begin{array}{c}0.458^{* * *} \\
(0.087)\end{array}$ & 0.060 & $\begin{array}{c}0.239 * * * \\
(0.068)\end{array}$ & 0.027 \\
\hline & Occupational prestige & + & $\begin{array}{l}0.184^{*} \\
(0.109)\end{array}$ & 0.007 & $\begin{array}{c}0.132 \\
(0.087)\end{array}$ & 0.005 \\
\hline & Mortality risk & + & $\begin{array}{l}0.118^{*} \\
(0.064)\end{array}$ & 0.008 & $\begin{array}{l}0.110^{* *} \\
(0.050)\end{array}$ & 0.011 \\
\hline & Competition & + & $\begin{array}{l}0.217 * * * \\
(0.067)\end{array}$ & 0.023 & $\begin{array}{c}0.285 * * * \\
(0.053)\end{array}$ & 0.061 \\
\hline & Time pressure & + & $\begin{array}{c}0.089 \\
(0.070)\end{array}$ & 0.004 & $\begin{array}{c}0.056 \\
(0.054)\end{array}$ & 0.003 \\
\hline & $\begin{array}{l}\text { Structured/. } \\
\text { unstructured work }\end{array}$ & + & $\begin{array}{c}0.033 \\
(0.073)\end{array}$ & 0.001 & $\begin{array}{l}-0.079 \\
(0.057)\end{array}$ & 0.004 \\
\hline & $\begin{array}{l}\text { Freedom to make } \\
\text { decisions }\end{array}$ & + & $\begin{array}{c}0.209 * * * \\
(0.074)\end{array}$ & 0.018 & $\begin{array}{l}0.142^{* *} \\
(0.058)\end{array}$ & 0.014 \\
\hline $\mathrm{R}^{2}$ & & & 0.630 & & 0.720 & \\
\hline
\end{tabular}

Notes: Authors' calculations from 1970 census and 2012 American Community Survey. The estimates for each year are from a regression of the log odds ratio of male to female employment at the occupational level on the indicated measures of occupational skills or aptitudes in the indicated year. ***, ** and * indicate statistical significance at the 10, 5 , and 1 percent levels respectively. 
Table 5: The relationship between the log odds ratio of male to female employment and the occupational aptitude "feeling", controlling for males' average height by occupation and other controls

\begin{tabular}{|c|c|c|c|c|c|c|}
\hline 1970 & & & & & & \\
\hline Feeling & $\begin{array}{l}-0.154^{*} \\
(0.091)\end{array}$ & $\begin{array}{c}-0.054 \\
(0.090)\end{array}$ & $\begin{array}{c}-0.425^{* * *} \\
(0.071)\end{array}$ & $\begin{array}{c}-0.268^{* * *} \\
(0.069)\end{array}$ & $\begin{array}{c}-0.306^{* * *} \\
(0.081)\end{array}$ & $\begin{array}{c}-0.242^{* * *} \\
(0.078)\end{array}$ \\
\hline Height & & $\begin{array}{c}0.910^{* * *} \\
(0.167)\end{array}$ & & $\begin{array}{c}1.273^{* * *} \\
(0.157)\end{array}$ & & $\begin{array}{c}0.998^{* * *} \\
(0.150)\end{array}$ \\
\hline \multicolumn{7}{|l|}{2012} \\
\hline Feeling & $\begin{array}{c}-0.132 \\
(0.082)\end{array}$ & $\begin{array}{c}-0.124 \\
(0.083)\end{array}$ & $\begin{array}{c}-0.457^{* * *} \\
(0.057)\end{array}$ & $\begin{array}{c}-0.369^{* * *} \\
(0.058)\end{array}$ & $\begin{array}{c}-0.319^{* * *} \\
(0.066)\end{array}$ & $\begin{array}{c}-0.283^{* * *} \\
(0.065)\end{array}$ \\
\hline Height & & $\begin{array}{c}0.077 \\
(0.154) \\
\end{array}$ & & $\begin{array}{c}0.672^{* * *} \\
(0.130) \\
\end{array}$ & & $\begin{array}{c}0.567^{* * *} \\
(0.120) \\
\end{array}$ \\
\hline \multicolumn{7}{|l|}{1990} \\
\hline Feeling & $\begin{array}{l}-0.134 \\
(0.081)\end{array}$ & $\begin{array}{c}-0.091 \\
(0.083)\end{array}$ & $\begin{array}{c}-0.474^{* * *} \\
(0.060)\end{array}$ & $\begin{array}{c}-0.361^{* * *} \\
(0.060)\end{array}$ & $\begin{array}{c}-0.325^{* * *} \\
(0.069)\end{array}$ & $\begin{array}{c}-0.282^{* * *} \\
(0.067)\end{array}$ \\
\hline Height & & $\begin{array}{l}0.391^{* *} \\
(0.153)\end{array}$ & & $\begin{array}{c}0.862^{* * *} \\
(0.134)\end{array}$ & & $\begin{array}{c}0.681^{* * *} \\
(0.124)\end{array}$ \\
\hline \multicolumn{7}{|l|}{ Controls } \\
\hline $\begin{array}{l}\text { Other } \\
\text { Attributes }\end{array}$ & & & $\mathrm{X}$ & $\mathrm{X}$ & $\mathrm{X}$ & $\mathrm{X}$ \\
\hline $\begin{array}{l}\text { S/M/S } \\
\text { Aptitudes }\end{array}$ & & & & & $\mathrm{X}$ & $\mathrm{X}$ \\
\hline
\end{tabular}

Notes: Authors' calculations from 1970, 1990 census and 2012 American Community Survey. This table shows the results from regressions of the log odds of male to female employment in the indicated year on the DOT attribute “feeling”, measures of males' average occupational height, and DOT code capturing competing hypotheses of gender based occupational segregation and sensory, perceptual motor and spatial (S/M/S) from the 1991 DOT. The height variable is constructed from the sample of men in the NHIS from 1990-1995. ***, ** and * indicate statistical significance at the 10,5 , and 1 percent levels respectively. 
Table 6: The interaction of height and job skill demands in predicting occupational selection (logit regressions)

\begin{tabular}{|c|c|c|c|}
\hline \multirow[b]{2}{*}{ Interaction with "height": } & \multicolumn{3}{|c|}{ Dependent variable: indicator for "individual i in occupation j" } \\
\hline & Men & Women & Difference \\
\hline \multicolumn{4}{|l|}{ Sensory } \\
\hline \multirow[t]{2}{*}{ Color discrimination } & $0.007^{* *}$ & 0.005 & 0.002 \\
\hline & $(0.003)$ & $(0.003)$ & $(0.004)$ \\
\hline \multirow{2}{*}{ Color vision } & -0.001 & -0.003 & 0.002 \\
\hline & $(0.002)$ & $(0.003)$ & $(0.004)$ \\
\hline \multirow[t]{2}{*}{ Near acuity } & 0.003 & 0.003 & -0.000 \\
\hline & $(0.002)$ & $(0.003)$ & $(0.003)$ \\
\hline \multirow[t]{2}{*}{ Far acuity } & 0.002 & $0.008 * * *$ & $-0.007 * *$ \\
\hline & $(0.002)$ & $(0.003)$ & $(0.003)$ \\
\hline \multirow[t]{2}{*}{ Hearing } & $0.011^{* * *}$ & $0.007^{*}$ & 0.004 \\
\hline & $(0.003)$ & $(0.003)$ & $(0.005)$ \\
\hline \multirow[t]{2}{*}{ Noise } & 0.001 & 0.000 & 0.000 \\
\hline & $(0.002)$ & $(0.003)$ & $(0.003)$ \\
\hline \multirow[t]{2}{*}{ Tasting/smelling } & -0.001 & $-0.004^{* * *}$ & 0.003 \\
\hline & $(0.001)$ & $(0.001)$ & $(0.002)$ \\
\hline \multirow{2}{*}{ Feeling } & $-0.005 * * *$ & $-0.008 * * *$ & 0.003 \\
\hline & $(0.002)$ & $(0.002)$ & $(0.003)$ \\
\hline \multicolumn{4}{|l|}{ Motor } \\
\hline \multirow[t]{2}{*}{ Fingering } & -0.000 & 0.001 & -0.002 \\
\hline & $(0.002)$ & $(0.003)$ & $(0.004)$ \\
\hline \multirow{2}{*}{ Finger dexterity } & -0.001 & $-0.011 * *$ & $0.009 * *$ \\
\hline & $(0.003)$ & $(0.004)$ & $(0.005)$ \\
\hline \multirow[t]{2}{*}{ Handling } & $-0.003^{* *}$ & -0.004 & 0.001 \\
\hline & $(0.002)$ & $(0.002)$ & $(0.003)$ \\
\hline \multirow{2}{*}{ Manual dexterity } & $-0.010 * * *$ & 0.006 & $-0.016 * * *$ \\
\hline & $(0.003)$ & $(0.004)$ & $(0.005)$ \\
\hline \multirow[t]{2}{*}{ Motor coordination } & -0.004 & 0.005 & $-0.009 * *$ \\
\hline & $(0.003)$ & $(0.003)$ & $(0.004)$ \\
\hline \multirow[t]{2}{*}{ Eye-hand-foot coordination } & 0.003 & 0.003 & -0.001 \\
\hline & $(0.003)$ & $(0.004)$ & $(0.004)$ \\
\hline \multirow{2}{*}{ Clerical perception } & $0.011^{* * *}$ & $0.015^{* * *}$ & -0.005 \\
\hline & $(0.003)$ & $(0.003)$ & $(0.005)$ \\
\hline \multicolumn{4}{|l|}{ Spatial } \\
\hline \multirow[t]{2}{*}{ Spatial aptitude } & $0.005^{*}$ & $0.014^{* * *}$ & $-0.009^{*}$ \\
\hline & $(0.005)$ & $(0.004)$ & $(0.005)$ \\
\hline \multirow[t]{2}{*}{ Depth perception } & $0.012 * * *$ & 0.002 & $0.010^{* *}$ \\
\hline & $(0.003)$ & $(0.004)$ & $(0.004)$ \\
\hline Other Attributes & & & \\
\hline Physical strength & $-0.007 * * *$ & -0.001 & -0.006 \\
\hline & $(0.003)$ & $(0.003)$ & $(0.004)$ \\
\hline GED - language & $0.012 * *$ & 0.001 & 0.012 \\
\hline & $(0.005)$ & $(0.005)$ & $(0.007)$ \\
\hline GED - math & -0.003 & 0.000 & -0.004 \\
\hline & $(0.004)$ & $(0.005)$ & $(0.007)$ \\
\hline Temperament - people & 0.000 & $0.007 *$ & -0.007 \\
\hline & $(0.003)$ & $(0.004)$ & $(0.005)$ \\
\hline Interest - things & -0.002 & -0.002 & 0.000 \\
\hline & $(0.002)$ & $(0.002)$ & $(0.003)$ \\
\hline
\end{tabular}




\begin{tabular}{lccc} 
Occupational prestige & $0.007^{* *}$ & 0.004 & 0.002 \\
& $(0.002)$ & $(0.004)$ & $(0.005)$ \\
Mortality risk & $0.017^{* *}$ & -0.010 & 0.017 \\
& $(0.003)$ & $(0.010)$ & $(0.010)$ \\
Competition & $0.008^{* * *}$ & $0.003^{*}$ & $0.005^{* *}$ \\
& $(0.002)$ & $(0.002)$ & $(0.002)$ \\
Time pressure & $-0.003^{* *}$ & $0.005^{* * *}$ & $-0.008^{* * *}$ \\
& $(0.002)$ & $(0.002)$ & $(0.002)$ \\
Structured/. unstructured & -0.001 & 0.000 & -0.001 \\
work & $(0.002)$ & $(0.002)$ & $(0.003)$ \\
Freedom to make decisions & $0.016^{* * *}$ & $0.010^{* * *}$ & $0.006^{*}$ \\
& $(0.002)$ & $(0.002)$ & $(0.003)$ \\
$\mathrm{N}$ & & & $1,478,628$ \\
\hline
\end{tabular}

Notes: Authors' calculations from the 1990-1994 NHIS. The sample for this table is the set of respondents in the NHIS who are aged 18-64, are employed in one of the 472 occupations that contain both men and women, and have non-missing height information. The table shows the results from a logit regression of an indicator for individual " $\mathrm{i}$ " being in occupation " $\mathrm{j}$ " on characteristics of the individual (3 race, 5 education and 8 age categories), occupational skill demands, height, and height interacted with all of the other individual and occupation level controls. The reported estimates are for the interaction of height with the indicated aptitude. ${ }^{* * *},{ }^{* *}$ and $*$ indicate statistical significance at the 10, 5, and 1 percent levels respectively. 
Table 7: Actual and simulated log odds regressions, controlling for the interaction between height and skill demands in job selection

\begin{tabular}{|c|c|c|c|c|}
\hline & $\begin{array}{l}\text { Actual - } 1990 \\
\text { Census }\end{array}$ & $\begin{array}{l}\text { Actual - NHIS, all } \\
\text { occupations }\end{array}$ & $\begin{array}{l}\text { Actual - NHIS, } \\
\text { restricted } \\
\text { occupations }\end{array}$ & $\begin{array}{c}\text { Predicted -NHIS, } \\
\text { shifting men to } \\
\text { female height } \\
\text { distribution }\end{array}$ \\
\hline \multicolumn{5}{|l|}{ Sensory } \\
\hline Color discrimination & $\begin{array}{c}-0.040 \\
(0.115)\end{array}$ & $\begin{array}{c}-0.065 \\
(0.122)\end{array}$ & $\begin{array}{c}-0.020 \\
(0.127)\end{array}$ & $\begin{array}{c}-0.176 \\
(0.131)\end{array}$ \\
\hline Color vision & $\begin{array}{c}-0.120 \\
(0.114)\end{array}$ & $\begin{array}{c}-0.055 \\
(0.121)\end{array}$ & $\begin{array}{c}-0.128 \\
(0.123)\end{array}$ & $\begin{array}{c}0.006 \\
(0.128)\end{array}$ \\
\hline Near acuity & $\begin{array}{l}-0.015 \\
(0.072)\end{array}$ & $\begin{array}{c}0.004 \\
(0.076)\end{array}$ & $\begin{array}{c}-0.032 \\
(0.078)\end{array}$ & $\begin{array}{c}-0.045 \\
(0.081)\end{array}$ \\
\hline Far acuity & $\begin{array}{c}0.241^{* * *} \\
(0.083)\end{array}$ & $\begin{array}{l}0.185^{* *} \\
(0.088)\end{array}$ & $\begin{array}{c}0.065 \\
(0.092)\end{array}$ & $\begin{array}{c}0.120 \\
(0.095)\end{array}$ \\
\hline Hearing & $\begin{array}{c}-0.006 \\
(0.117)\end{array}$ & $\begin{array}{c}0.011 \\
(0.125)\end{array}$ & $\begin{array}{c}-0.016 \\
(0.132)\end{array}$ & $\begin{array}{c}-0.095 \\
(0.137)\end{array}$ \\
\hline Noise & $\begin{array}{c}0.250^{* * *} \\
(0.081)\end{array}$ & $\begin{array}{c}0.239^{* * *} \\
(0.086)\end{array}$ & $\begin{array}{c}0.251^{* * *} \\
(0.093)\end{array}$ & $\begin{array}{l}0.197^{* *} \\
(0.096)\end{array}$ \\
\hline Tasting/smelling & $\begin{array}{c}-0.070 \\
(0.054)\end{array}$ & $\begin{array}{c}-0.045 \\
(0.057)\end{array}$ & $\begin{array}{c}-0.046 \\
(0.056)\end{array}$ & $\begin{array}{c}0.072 \\
(0.058)\end{array}$ \\
\hline Feeling & $\begin{array}{c}-0.325^{* * *} \\
(0.068)\end{array}$ & $\begin{array}{c}-0.342^{* * *} \\
(0.073)\end{array}$ & $\begin{array}{c}-0.307^{* * *} \\
(0.074)\end{array}$ & $\begin{array}{c}-0.170^{* *} \\
(0.077)\end{array}$ \\
\hline \multicolumn{5}{|l|}{ Motor } \\
\hline Fingering & $\begin{array}{c}0.096 \\
(0.089)\end{array}$ & $\begin{array}{c}0.148 \\
(0.095)\end{array}$ & $\begin{array}{c}0.151 \\
(0.098)\end{array}$ & $\begin{array}{c}0.133 \\
(0.101)\end{array}$ \\
\hline Finger dexterity & $\begin{array}{c}-0.248^{* *} \\
(0.108)\end{array}$ & $\begin{array}{c}-0.323^{* *} \\
(0.114)\end{array}$ & $\begin{array}{c}-0.346^{* * *} \\
(0.119)\end{array}$ & $\begin{array}{c}-0.168 \\
(0.123)\end{array}$ \\
\hline Handling & $\begin{array}{c}-0.092 \\
(0.081)\end{array}$ & $\begin{array}{c}-0.123 \\
(0.086)\end{array}$ & $\begin{array}{c}-0.239^{* *} \\
(0.096)\end{array}$ & $\begin{array}{c}-0.272^{* *} \\
(0.099)\end{array}$ \\
\hline Manual dexterity & $\begin{array}{c}0.027 \\
(0.131)\end{array}$ & $\begin{array}{c}-0.041 \\
(0.140)\end{array}$ & $\begin{array}{c}-0.026 \\
(0.141)\end{array}$ & $\begin{array}{c}-0.022 \\
(0.147)\end{array}$ \\
\hline Motor coordination & $\begin{array}{c}0.002 \\
(0.105)\end{array}$ & $\begin{array}{c}0.051 \\
(0.112)\end{array}$ & $\begin{array}{c}0.127 \\
(0.118)\end{array}$ & $\begin{array}{c}0.038 \\
(0.123)\end{array}$ \\
\hline $\begin{array}{l}\text { Eye-hand-foot } \\
\text { coordination } \\
\text { Clerical perception }\end{array}$ & $\begin{array}{c}-0.206^{* *} \\
(0.081) \\
-0.185 \\
(0.113) \\
\end{array}$ & $\begin{array}{c}-0.218^{* *} \\
(0.086) \\
-0.208^{*} \\
(0.120) \\
\end{array}$ & $\begin{array}{c}-0.075 \\
(0.096) \\
-0.129 \\
(0.129) \\
\end{array}$ & $\begin{array}{c}-0.108 \\
(0.100) \\
-0.318^{* *} \\
(0.134)\end{array}$ \\
\hline \multicolumn{5}{|l|}{$\overline{\text { Spatial }}$} \\
\hline Spatial aptitude & $\begin{array}{c}0.481^{* * *} \\
(0.104)\end{array}$ & $\begin{array}{c}0.513^{* * *} \\
(0.110)\end{array}$ & $\begin{array}{c}0.610^{* * *} \\
(0.121)\end{array}$ & $\begin{array}{c}0.414^{* * *} \\
(0.125)\end{array}$ \\
\hline Depth perception & $\begin{array}{c}0.309^{* * *} \\
(0.104)\end{array}$ & $\begin{array}{l}0.351^{* *} \\
(0.110)\end{array}$ & $\begin{array}{c}0.319^{* * *} \\
(0.114)\end{array}$ & $\begin{array}{l}0.283^{* *} \\
(0.119)\end{array}$ \\
\hline \multicolumn{5}{|l|}{ Other Attributes } \\
\hline Physical strength & $\begin{array}{c}0.502^{* * *} \\
(0.105)\end{array}$ & $\begin{array}{c}0.496^{* * *} \\
(0.111)\end{array}$ & $\begin{array}{c}0.504^{* * *} \\
(0.114)\end{array}$ & $\begin{array}{c}0.331^{* * *} \\
(0.118)\end{array}$ \\
\hline GED - language & -0.258 & -0.322 & -0.314 & $-0.381^{*}$ \\
\hline
\end{tabular}




\begin{tabular}{lcccc} 
& $(0.188)$ & $(0.199)$ & $(0.214)$ & $(0.222)$ \\
GED - math & $0.576^{* * *}$ & $0.600^{* * *}$ & $0.435^{* *}$ & $0.440^{* * *}$ \\
& $(0.160)$ & $(0.169)$ & $(0.183)$ & $(0.190)$ \\
Temperament - & -0.153 & -0.110 & -0.027 & -0.202 \\
people & $(0.117)$ & $(0.125)$ & $(0.136)$ & $(0.141)$ \\
Interest - things & $0.259^{* * *}$ & $0.260^{* * *}$ & $0.254^{* * *}$ & $0.273^{* * *}$ \\
& $(0.072)$ & $(0.076)$ & $(0.075)$ & $(0.078)$ \\
Occupational prestige & 0.081 & 0.097 & 0.200 & 0.079 \\
& $(0.109)$ & $(0.115)$ & $(0.125)$ & $(0.130)$ \\
Mortality risk & $0.124^{* *}$ & $0.114^{*}$ & 0.082 & 0.057 \\
& $(0.056)$ & $(0.059)$ & $(0.058)$ & $(0.060)$ \\
Competition & $0.275^{* * *}$ & $0.284^{* * *}$ & $0.303^{* * *}$ & $0.250^{* * *}$ \\
& $(0.061)$ & $(0.065)$ & $(0.067)$ & $(0.070)$ \\
Time pressure & 0.016 & -0.014 & -0.008 & -0.067 \\
& $(0.061)$ & $(0.065)$ & $(0.065)$ & $(0.068)$ \\
Structured/. & $-0.134^{*}$ & -0.121 & $-0.172^{* *}$ & $-0.206^{* *}$ \\
unstructured work & $(0.072)$ & $(0.077)$ & $(0.080)$ & $(0.083)$ \\
Freedom to make & $0.336^{* * *}$ & $0.300^{* * *}$ & $0.288^{* * *}$ & $0.196^{* *}$ \\
decisions & $(0.062)$ & $(0.066)$ & $(0.069)$ & $(0.072)$ \\
& & & & \\
$\mathrm{N}$ & 472 & 472 & 415 & 415 \\
$\mathrm{R}^{\wedge} 2$ & 0.666 & 0.630 & 0.659 & 0.621 \\
\hline
\end{tabular}

Notes: Authors' calculations from 1990 census and 1990-1994 NHIS. This table shows the results from regressions of the log odds of male to female employment on DOT and O*NET skill demand measures. The results in column (1) through (3) are from regressions using the actual log odds in the indicated surveys/samples. The results in column (4) are for the log odds that would be predicted if men had the same height distribution as women based on the regression results in Table 3. ${ }^{* * *}$, ** and * indicate statistical significance at the 10,5 , and 1 percent levels respectively. 
Table 8: Predicted Duncan indices negating occupational selection on occupational skills, aptitudes and attributes; univariate results

\begin{tabular}{|c|c|c|c|c|c|}
\hline & & \multicolumn{2}{|c|}{1970} & \multicolumn{2}{|c|}{2012} \\
\hline & & Duncan & $\begin{array}{c}\% \Delta \text { from } \\
\text { Actual }\end{array}$ & Duncan & $\begin{array}{c}\% \Delta \text { from } \\
\text { Actual }\end{array}$ \\
\hline Actual & & 0.644 & & 0.508 & \\
\hline \multirow[t]{8}{*}{ Sensory } & Color discrimination & 0.646 & 0.3 & 0.502 & -1.2 \\
\hline & Color vision & 0.648 & 0.6 & 0.500 & -1.6 \\
\hline & Near Acuity & 0.636 & -1.2 & 0.489 & -3.7 \\
\hline & Far Acuity & 0.636 & -1.2 & 0.498 & -2.0 \\
\hline & Hearing & 0.625 & -3.0 & 0.473 & -6.9 \\
\hline & Noise & 0.619 & -3.9 & 0.445 & -12.4 \\
\hline & Tasting-smelling & 0.643 & -0.2 & 0.510 & 0.4 \\
\hline & Feeling & 0.641 & -0.5 & 0.504 & -0.8 \\
\hline \multirow[t]{7}{*}{ Motor } & Fingering & 0.610 & -5.3 & 0.494 & -2.8 \\
\hline & Finger Dexterity & 0.633 & -1.7 & 0.505 & -0.6 \\
\hline & Handling & 0.644 & 0.0 & 0.509 & 0.2 \\
\hline & Manual dexterity & 0.648 & 0.6 & 0.518 & 2.0 \\
\hline & Motor Co-ordination & 0.651 & 1.1 & 0.519 & 2.2 \\
\hline & Eye-Hand-Foot & 0.627 & -2.6 & 0.470 & -7.5 \\
\hline & Clerical Perception & 0.620 & -3.7 & 0.454 & -10.6 \\
\hline \multirow[t]{2}{*}{ Spatial } & Spatial skills & 0.580 & -9.9 & 0.475 & -6.5 \\
\hline & Depth perception & 0.577 & -10.4 & 0.426 & -16.1 \\
\hline Other & Physical strength & 0.607 & -5.7 & 0.476 & -6.3 \\
\hline \multirow[t]{10}{*}{ Attributes } & GED - language & 0.645 & 0.2 & 0.507 & -0.2 \\
\hline & GED - math & 0.635 & -1.4 & 0.509 & 0.2 \\
\hline & Temperament - people & 0.628 & -2.5 & 0.481 & -5.3 \\
\hline & Interest - things & 0.623 & -3.3 & 0.495 & -2.6 \\
\hline & Occupational prestige & 0.640 & -0.6 & 0.511 & 0.6 \\
\hline & Mortality rate & 0.627 & -2.6 & 0.487 & -4.1 \\
\hline & Competition & 0.612 & -5.0 & 0.497 & -2.2 \\
\hline & Time pressure & 0.629 & -2.3 & 0.490 & -3.5 \\
\hline & Structured/unstructured work & 0.643 & -0.2 & 0.508 & 0.0 \\
\hline & Freedom to make decisions & 0.633 & -1.7 & 0.507 & -0.2 \\
\hline
\end{tabular}

Notes: Authors' calculations from 1970 census and 2012 American Community Survey. The predicted Duncan indices are constructed as per equation (3) in the text based on the estimates in Table 3. All predicted indices are statistically significantly different from the actual Duncan index in the indicated year at the 1 percent level. 
Table 9: Predicted Duncan indices negating occupational selection on occupational skills, aptitudes and attributes; multivariate results

\begin{tabular}{lcccc}
\hline & \multicolumn{2}{c}{1970} & \multicolumn{2}{c}{2012} \\
\hline Actual & Duncan & $\begin{array}{c}\% \Delta \text { from } \\
\text { Actual }\end{array}$ & Duncan & $\begin{array}{c}\% \Delta \text { from } \\
\text { Actual }\end{array}$ \\
\hline Sensory & 0.644 & & 0.508 & \\
Motor & 0.617 & -4.2 & 0.472 & -7.1 \\
Spatial & 0.611 & -5.1 & 0.491 & -3.3 \\
Combined: sensory, & 0.510 & -20.8 & 0.393 & -10.4 \\
motor and spatial & 0.574 & -10.9 & 0.455 & -6.3 \\
Physical strength & 0.622 & -3.4 & 0.476 & 0 \\
Cognitive & 0.632 & -1.9 & 0.508 & -4.3 \\
People/things & 0.627 & -2.6 & 0.486 & -2.0 \\
Occupational risk & 0.623 & -3.3 & 0.498 & -1.2 \\
Flexibility & 0.627 & -2.6 & 0.502 & -18.3 \\
Combined - Other & 0.551 & -14.4 & 0.415 & \\
Attributes & & & & 0.299 \\
\hline All & 0.420 & -34.8 & & \\
\hline
\end{tabular}

Notes: Authors' calculations from 1970 census and 2012 American Community Survey. "Cognitive includes GED—language and GED—math. "People/Things" includes temperament—people and interest—things. "Occupational risk" includes occupational prestige, mortality risk and competition. "Flexibility" includes time pressure, structured/unstructured work and freedom to make decisions. The predicted Duncan indices are constructed as per equation (3) in the text based on the estimates in Table 4. All predicted indices are statistically significantly different from the actual Duncan index in the indicated year at the 1 percent level. 